\title{
Estimation and Analysis of Labor Demand Function in Terms of Education and Employment Forecasting Up to the Year 1400
}

\author{
Alireza Amini ${ }^{1}$ \\ Behnam Nikbin²
}

\author{
ar.amini@iauctb.ac.ir \\ nikbin.behnam@atu.ac.ir
}

\begin{abstract}
The highly-educated labor force unemployment rate rapidly overtook the unemployment rate of the less-educated workers for the last two decades. This paper focuses on the factors which affect labor demand considering the level of education using the data from 1986 to 2017. Results based on the Multiple-Equation Generalized Method of Moments estimator demonstrate that non-oil GDP, relative wages, capital-labor ratio, and labor costs-capital costs ratio have a significant impact on labor demand in terms of education level. Also, it is demonstrated that the highlyeducated labor force can adjust to its desired level at a slower pace than the less educated workforce. Furthermore, it is denoted that non-oil GDP affects labor demand in a positive and significant way with more impact on the workers with higher education. Other findings indicate that in Iran's labor market, highly-educated labor force and workers without college/ university degree are substitutes, hence policies like wage subsidies and employer insurance exemption for employing higher education graduates can stimulate labor demand for a highly-educated workforce in a positive and significant manner. On the other hand, as it is found that labor and capital are substitutes, policies that make labor costlier than capital may result in employment reduction. Finally, the technological progress that arises from increases in capital per capita has a positive and significant effect on the labor force with higher education, but it influences less-educated labor employment negatively and significantly.
\end{abstract}

Keywords: Highly-Education Labor Demand, Adjustment Costs, Capital Intensive, Technological Progress, Multiple-Equation GMM, Active Labor Market Policies.

JEL Classification: E24, J23, J24.

\footnotetext{
1. Associate Professor, Faculty of Economics and Accounting, Islamic Azad University, Central Tehran Branch, Tehran, Iran (Corresponding Author).

2. M.A. in Economic Development and Planning, Allameh Tabataba'i University, Tehran, Iran.
} 


\section{برآورد و تحليل تابع اشتغال برحسب سطح سواد و ييشبينى اشتغال تا سال + +ـعا}

ar.amini@iauctb.ac.ir

دانشيار دانشكده اقتصادو حسابدارى دانشعاه آزاد اسلامى واحد تهران

مركزى (نويسنده مسئول).

nikbin.behnam@atu.ac.ir |

بهنام نيكبين

دانشآموخته كارشناسى ارشد توسعه اقتصادى و برنامهريزى

دانشخاه علامه طباطبيى، تهران.

مقاله بزوهشى

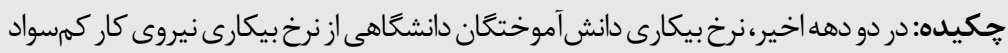

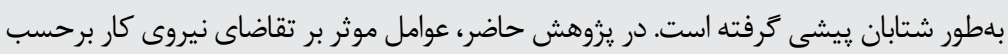

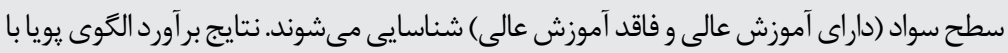

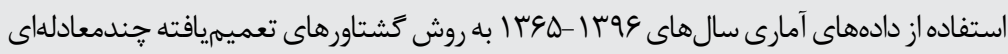

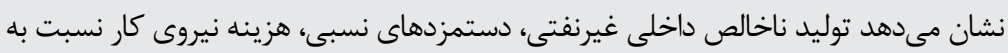

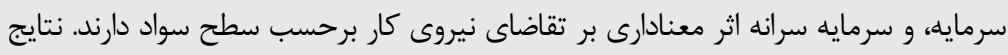

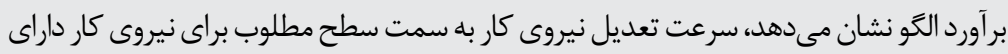

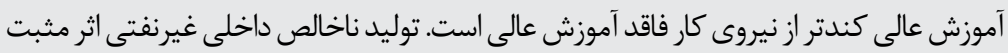

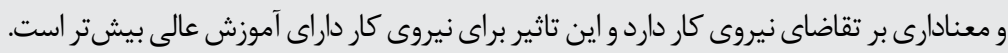

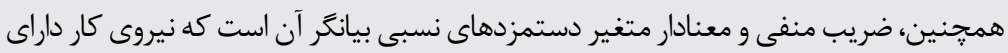

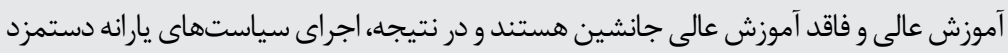

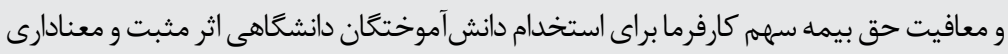

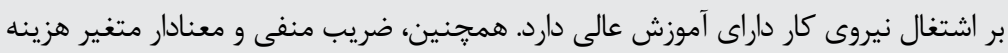

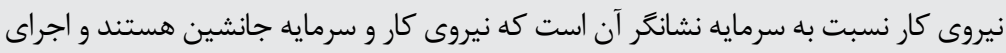

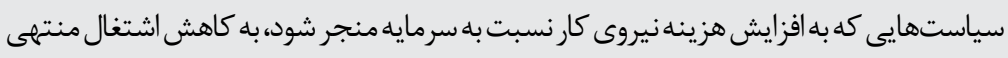

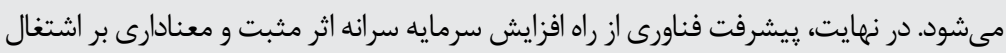

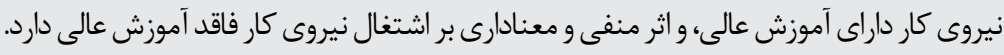

كليدوازهها: تقاضاى نيروى كار داراى آموزش عالى، هزينههاى تعديل، سرمايهبرى، يِيشرفت

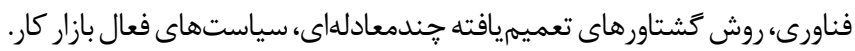




\section{مقلفمه}

يكى از تحولهاى مهلم در بازار كار ايران، تغيير ساختار نيروى كار برحسب سطح سواد است.

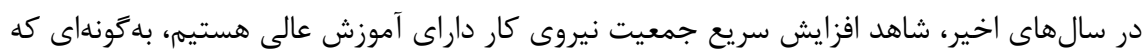

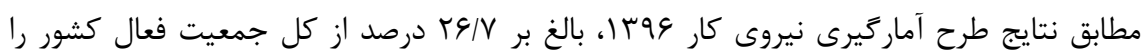
جمعيت دانشآموخته داراى آموزش عالى تشكيل مى دهند. اين در حالى است كه اين شاخص در در

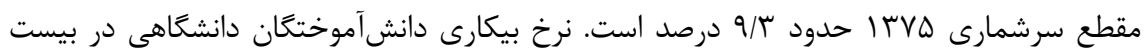

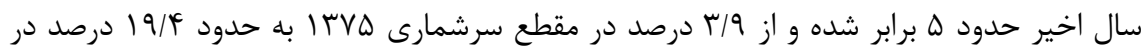

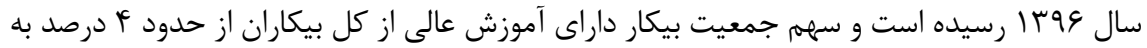

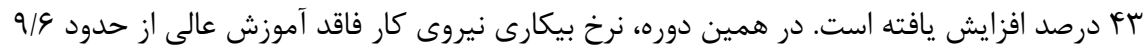

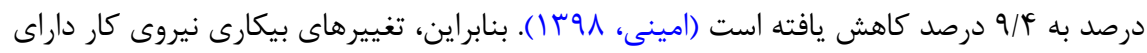

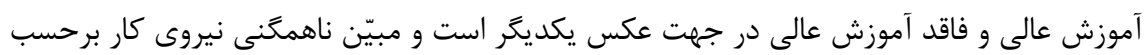
سطح سواد است. براى كاهش فاصله نرخ بيكارى اين دو گروه از نيروى كار به سياستهاى ويزٔه بازار

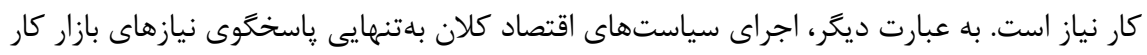

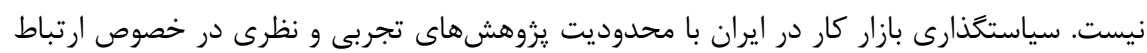

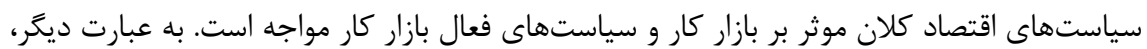

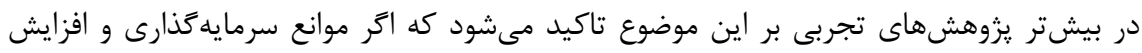

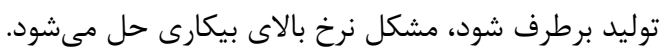

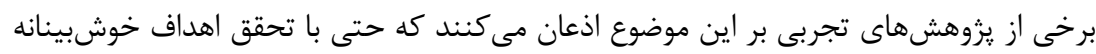

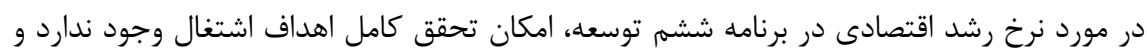

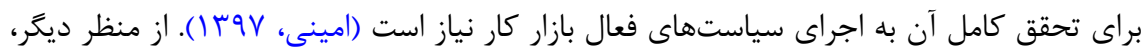

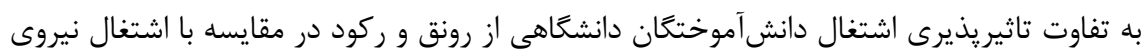
كار كمسواد كمتر يرداخته مىشود. سياستخذار درك روشنى از ضرورت اجراى سياستهاى فعال

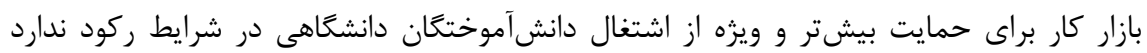

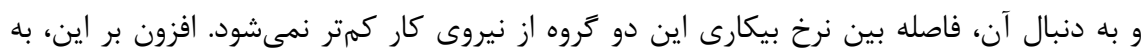

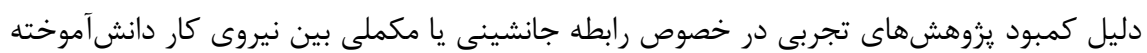

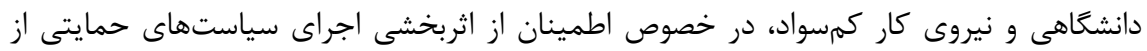

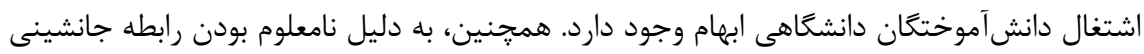


يا مكملى بين كار و سرمايه، در خصوص اثرهاى سياست ڤرداخت يارانه سود تسهيلات بانكى بر

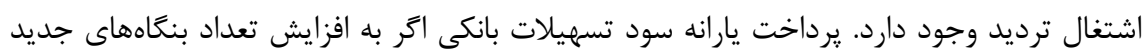

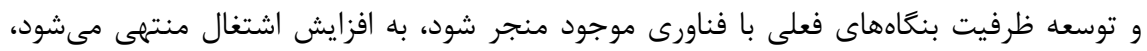
ولى اگر به توسعه فناورى و جايگزينى سرمايه بهجاى نيروى كار منتهى شود، نتيجه آن كاهش

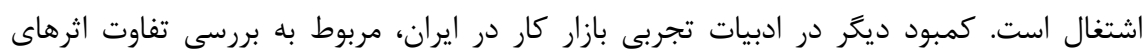
توسعه فناورى بر اشتغال نيروى كار دانش آموخته دانشگاهى و نيروى كمسواد در سطح كلان اقتصاد

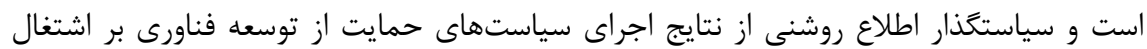

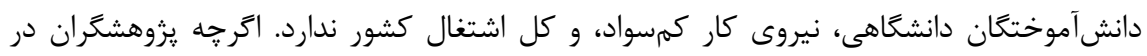

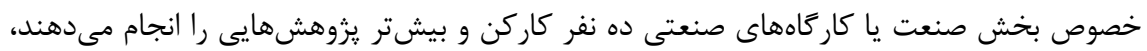
ولى فقر يزوهشها در سطح كلان اقتصاد حس مى بـود.

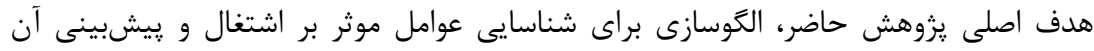

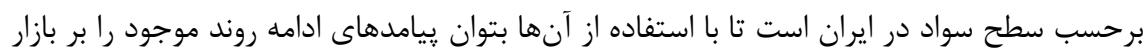

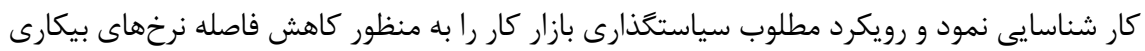
دانشآموختخان دانشَاهى با نيروى كار كمسواد معرفى كرد. سعى مىشود در اين ارتباط بر اساس باس

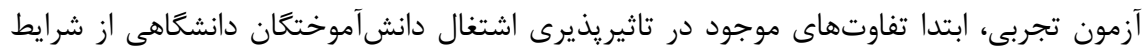

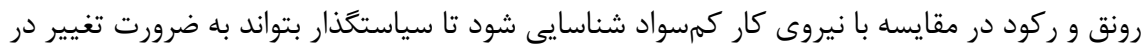

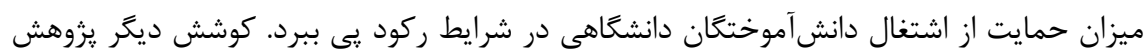
در اين مسير است كه با توجه به شرايط اقتصاد ايران، روشن كند كه اجراى سياستهاى كاهش هزينه استفاده از نيروى كار داراى آموزش عالى در مقايسه با هزينههاى استفاده از نيروى كار كمسواد

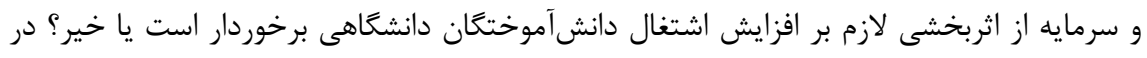
نهايت، نتايج يزوهش حاضر به سياستخذار كمك مى كند كه به اثرهاى توسعه فناورى بر اشتغال

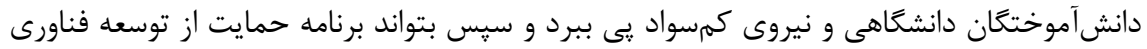
در بنغاهها را در راستاى افزايش اشتغال دانش آموختخان دانشَاهى عملياتى نمايد. 


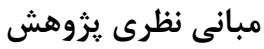

\section{تقاضاى نيروى كار}

در مباحث اوليه اقتصاد خرد با فرض همخَنى نيروى كار، تقاضاى نيروى كار عبارت است از

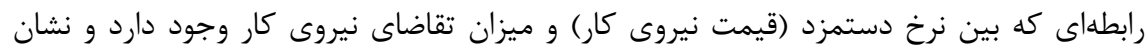

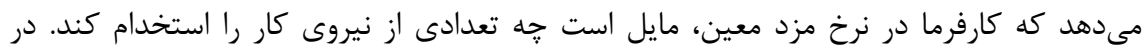
اين تعريف، يك فرض اساسى وجود دارد كه مربوط به فرض ثابت بودن ساير عوامل همانند سطح مائ مرد

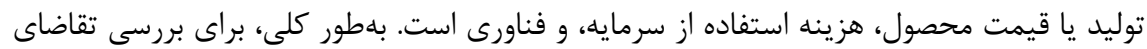

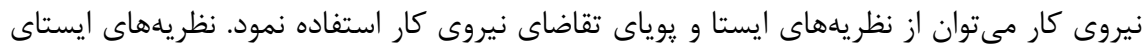

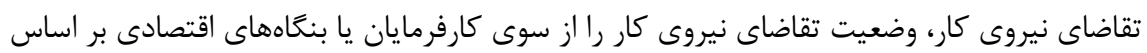
بيشينهسازى تابع سود يا كمينهسازى هزينه در يك مقطع زمانى معين مورد تجزيلهوتحليل قرار

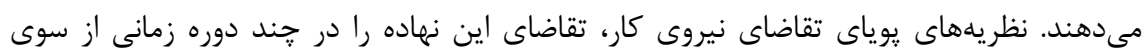
واحدهاى توليدى در نظر مى گيرند. در نظريههاى يويا، تفاوت بين تقاضاى واقعى و مطلوب براى

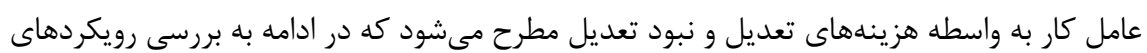
يادشده ״رداخته مىشود.

\section{نظريههاى ايستاى تقاضاى كار}

\section{الف. روش بيشينه كردن سود بنحاه}

در ادبيات كلاسيك اقتصاد، مىتوان از بيشينه كردن سود بنگاه براى تعيين تقاضاى بنحاه براى

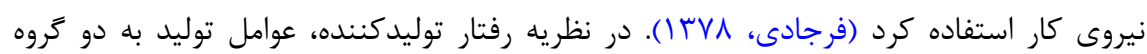

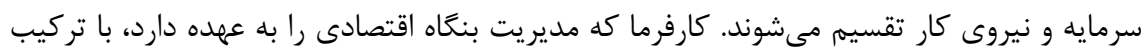
سرمايه و نيروى كار به توليد محصول مىيردازد. هر يك از عوامل توليد (سرمايه و نيروى كار)، اجرت

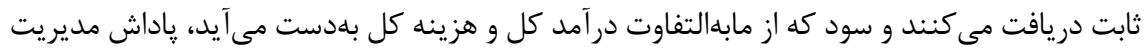
و تحمل ريسك كارفرماست. اگر از تابع سود بنگًاه نسبت به قيمتهاي نيروى كار و و سرمايه مشتق

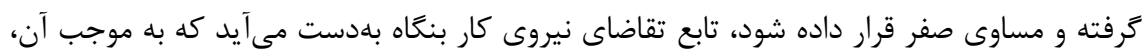

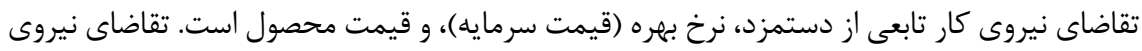


كار با دستمزد رابطه غيرمستقيم و با قيمت محصول رابطه مستقيم دارد. با توجه به رابطه جانشينى يا مكملى بين كار و سرمايه، تقاضاى نيروى كار مىتواند رابطه مستقيم يا غيرمستقيم با نرخ بهره داشته باشد.

اين روش به كمينهسازى مخارج بنگاه در يك سطح مشخصى از توليد و قيمت مى ميردازد و و

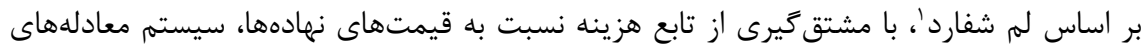

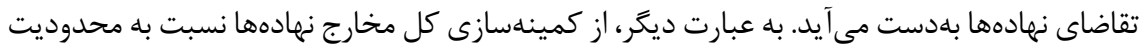
فناورى براى ستانده مفروض و قيمتهاى مفروض نهادهها، توابع تقاضا براى نهادهها به صورت تابعى از

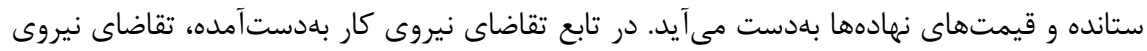

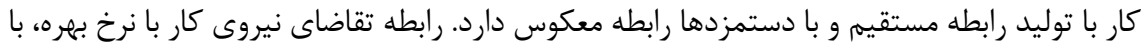
توجه به رابطه جانشينى و مكملى بين كار و سرمايه مىتواند بهترتيب مثبت و منفى باشد.

\section{نظريdهاى پيوياى تقاضاى كار}

نظريه ايستاى تقاضاى نيروى كار در رابطه با مسير تعديل (طول دوره زمانى تعديل) در رسيدن به

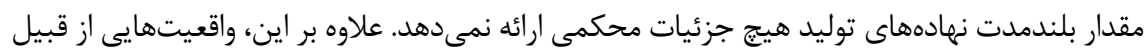
محدوديتهاى فناورانه، نوسانهاى بازار، و تحرك نيروى كار را كه بنكاههاى اقتصادى در فرايند تعديل

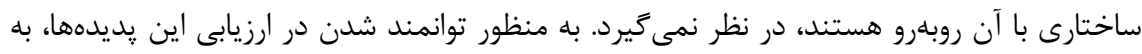
مفهوم هزينه تعديل متوسل مىشوند كه به صورت خاص بر زيان ايجادشده ناشى از تغيير كمّى عامل توليد تمركز مى كند. فرم تبعى كه براى توصيف هزينههاى تعديل بكار زرفته مىشود، مدل يوياى تقاضاى نيروى كار و راهحل پايدار را تعيين و مشروط مى كند (Cahuc \& Zylberberg, 2004).

\section{هزينههاى تعديل نيروى كار}

مخارجى كه هنگَام تعديل تعدادى از نيروى كار به بنگًاه تحميل مىشود، هزينههاى تعديل ناميده

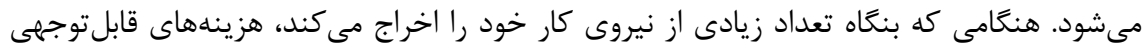
متحمل مى شود كه براى مثال مى تواند شامل از دست رفتن تجربه و دانش آن نيروى كار در خط 
توليد بنگاه باشد. از منظر ديگر، هنگامى كه بنگاه اقدام به استخدام نيروى كار جديد مى كند،

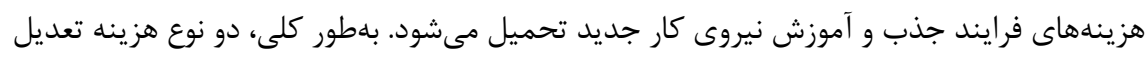
وجود دارد: هزينههاى تعديل متغير و هزينههاى تعديل ثابت. هزينه تعديل متغير، به تعداد نيروى كارى بستخى دارد كه بنگًاه استخدام يا اخراج مى كند. براى مثال، هزينههاى آموزش نيروى كار

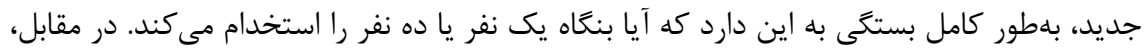
هزينههاى تعديل ثابت به تعداد استخدام و اخراج نيروى كار بستكى ندارد. هزينههايى كه در اثر

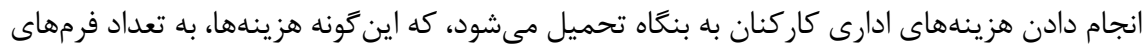

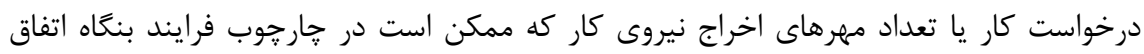

بيافتد، بستخى ندارد (Borjas, 2005).

\section{ناهمگَى نيروى كار}

وقتى بحث ناهمًَنى نيروى كار مطرح مىشود، منظور اين است كه دست كم با دو نوع نيروى

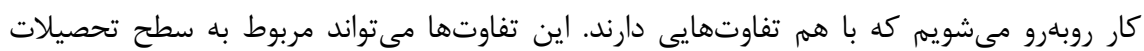
و مهارت باشد كه بهطور معمول نيروى كار را به دو گروه داراى تحصيلات عالى و فاقد تحصيلات

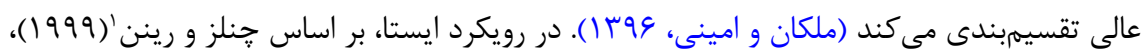

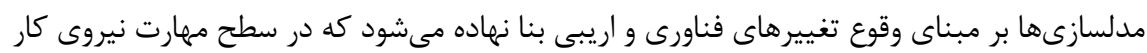

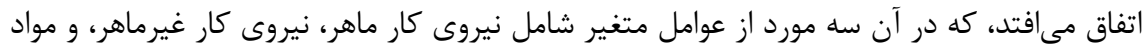

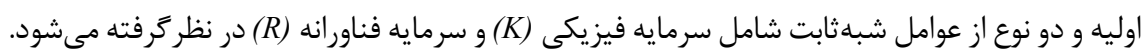

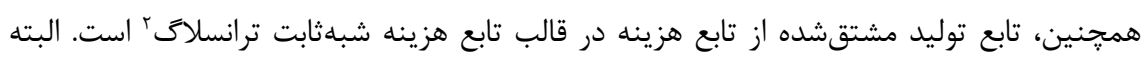

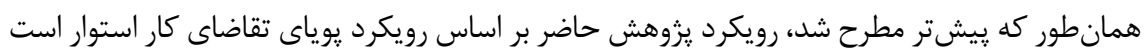
كه در ادامه به استخراج آن با لحاظ شرط ناهمگنى نيروى كار برحسب سطح سواد يرداخته مى شود.

\section{تابع تقاضاى یوياى نيروى كار بنًَاه بر اساس ناهمگنى نيروى كار برحسب سطح سواد} براى استخراج تابع تقاضاى نيروى كار، فرض بر آن است كه فناورى توليد بنَاه از تابع كاب

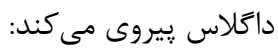

1. Chennells \& Reenen

2. Translog Quasi-fixed Cost Function 
$Q_{n t}=A e^{D_{t}} K_{n t}^{\beta} L_{1 n t}^{a_{1}} L_{2 n t}^{a_{2}}$

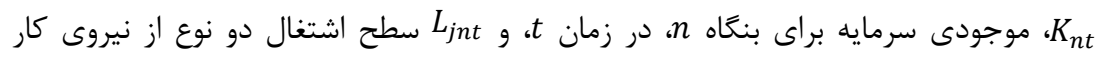

(j=1،2) برحسب سطح سواد يا جنسيت، و t

بر آن است كه بنگًاه مقدار توليد انتظارى' را تعيين مى كند (يعنى بنگًاه با محدوديت مقدارى توليد مواجه است). بر اساس اين، بنگاه به دنبال كمينه كردن هزينههاست:

$C_{t}=E_{t} \sum_{\tau=0}^{\infty}\left(\frac{1}{1+r}\right)^{\tau}\left[c_{t+\tau} K_{t+\tau}+\sum_{j=1}^{2} w_{j, t+\tau}+\sum_{j=1}^{p} \frac{d_{j}}{2}\left(L_{j, t+\tau}-L_{j, t+\tau-1}\right)^{2}\right.$ $\left.\frac{e}{2}\left(K_{t+\tau}-K_{t+\tau-1}\right)^{2}\right]$

تحت محدوديت مقدارى توليد خواهيم داشت:

$Q_{t+\tau}=A e^{D_{t+\tau}} K_{t+\tau}^{\beta} L_{1 t+\tau}^{a_{1}} L_{2 t+\tau}^{a_{2}}$

oct ، هزينه استفاده از سرمايه كه شامل قيمت كالاهاى سرمايهاى، نرخ استهلاك سرمايه، و نرخ بهره است. و سرمايه و r، شاخص نرخ تنزيل است.

بنابراين، شرط مرتبه اول (معادله اولر) براى اشتغال به صورت رابطه (Y) نوشته مىشود: $E_{t}\left(-\frac{1}{1+r} d_{j}\left(L_{j, t+\tau+1}-L_{j, t+\tau}\right)+d_{j}\left(L_{j, t+\tau}-L_{j, t+\tau-1}\right)+w_{j, t+\tau}+\right.$ $\left.\lambda_{t+\tau} \frac{\partial Q}{\partial N_{j, t+\tau}}\right)=0 \forall \tau, j=1,2$

و براى سرمايه: - n

$E_{t}\left(-\frac{1}{1+r} e\left(K_{t+\tau+1}-K_{t+\tau}\right)+e\left(K_{t+\tau}-K_{t+\tau-1}\right)+c_{t+\tau}+\lambda_{t+\tau} \frac{\partial Q}{\partial K_{, t+\tau}}\right)=0 \forall \tau(\Delta)$

يكى از راههاى حل اين سيستم، قضيه مشتق ضمنى و خطى كردن در حوالى تعادل بلندمدت

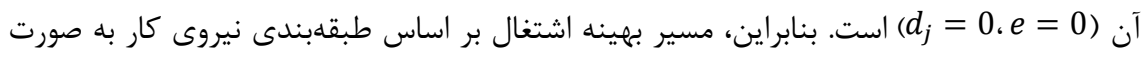
رابطه (؟) است:

$\mathrm{L}_{\mathrm{jt}}=\mu_{\mathrm{j}} \mathrm{L}_{\mathrm{j}, \mathrm{t}-1}+\left(1+\mu_{\mathrm{j}}\right)\left(1-\mathrm{Q}_{\mathrm{j}} \mu_{\mathrm{j}}\right) \sum_{\tau=0}^{\infty}\left(\varrho_{\mathrm{j}} \mu_{\mathrm{j}}\right)^{\tau} \mathrm{L}_{\mathrm{j}, \mathrm{t}+\tau}^{*}, \mathrm{j}=1,2$

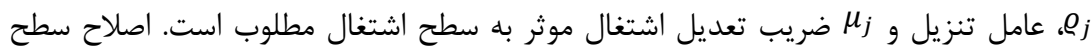
مطلوب اشتغال مىتواند از حل بهينهسازى بنگاه بدون هزينههاى تعديل مشتق شود. بنابراين، به 


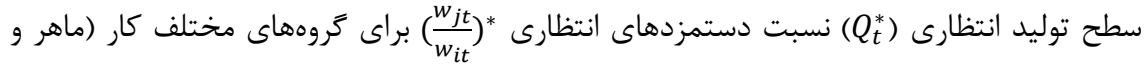
غيرماهر)، نسبت هزينههاى نيروى كار به سرمايه ${ }^{*}$

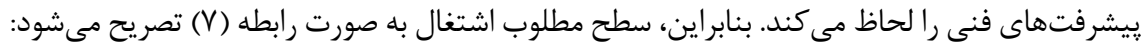
$\log L_{j, t+\tau}^{*}=a_{1} \log Q_{t+\tau}^{*}+\sum_{i \neq j} a_{2 i} \log \left(\frac{w_{j}}{w_{i}}\right)_{t+\tau}^{*}+a_{3} \log \left(\frac{w_{j}}{c}\right)_{t+\tau}^{*}+D_{t+\tau}+a_{4}+\varepsilon_{j, t+\tau}(\mathrm{\vee})$ كه اين رابطه به صورت رابطه (^) قابل بازنويسى است:

$\log _{j, t+\tau}^{*}=\beta_{j} E_{t}\left(y_{j, t+\tau}\right)+D_{t+\tau}+a_{4}+\varepsilon_{j, t+\tau}$

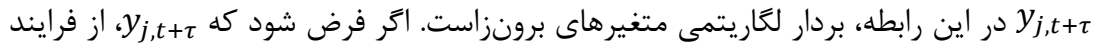

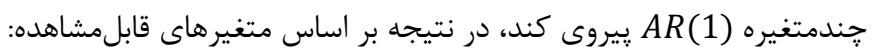
$\log L_{j, t}=\mu_{j} \log L_{j, t-1}+a_{0 j} \log Q_{t}+a_{1 j} \log Q_{t-1}+\sum_{i \neq j} \gamma_{0 i} \log \left(\frac{w_{j}}{w_{i}}\right)_{t}+$ $\sum_{i \neq j} \gamma_{1 i} \log \left(\frac{w_{j}}{w_{i}}\right)_{t-1}+\beta_{0 j} \log \left(\frac{w}{c}\right)_{t}+\beta_{1 j} \log \left(\frac{w}{c}\right)_{t-1}+\gamma_{j} D_{t}+\delta_{j}+\omega_{j, t}, j=1,2^{(9)}$ در نهايت، اگر فرض شود كه نسبت هزينههاى نسبى نيروى كار در طول زمان ثابت است، در اين صورت، مدل براى نيروى كار از نوع به صورت رابطه (• (1) مىشود: $\log L_{j, t}=\mu_{j} \log L_{j, t-1}+a_{0 j} \log Q_{t}+a_{1 j} \log Q_{t-1}+\beta_{0 j} \log \left(\frac{w}{c}\right)_{t}+\beta_{1 j} \log \left(\frac{w}{c}\right)_{t-1}+(1 \cdot)$ $\gamma_{j} D_{t}+\delta_{j}+\omega_{j t}, j=1,2$

نياز به يادآورى است كه زف، متغيرى برونزا غير از دستمزد است.

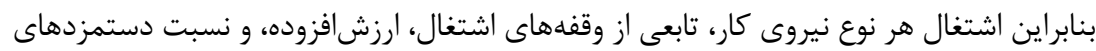

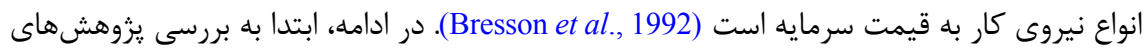

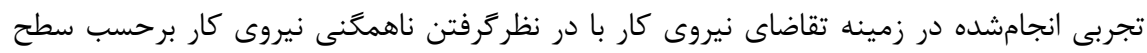
سواد يرداخته مىشود.

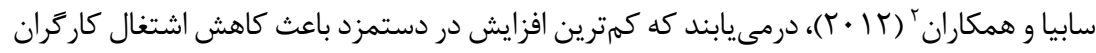
بلوويزه گروه سنى 9ץ-19 ساله با تحصيلات و مهارت كم مىشود. نتايج جنلز و رينن (999 (1)، نشان مى دهد كه فناورى اثر منفى بر اشتغال و دستمزد نيروى كار غيرماهر و اثر مثبت بر اشتغال و دستمزد نيروى كار ماهر دارد. همجنين، اندازه فناورى با ساختار مهارت ارتباط دارد و به نفع نيروى كار ماهر است.

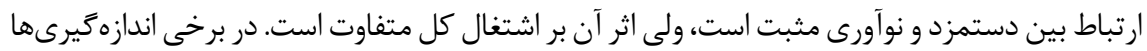
(كستردگى توليد)، نوآورى در توليد موجب گسترش دامنه محصولات و افزايش اشتغال مىشود (ارتباط 
مثبت) و در برخى ديخر (بر مبناى R\&D) منفى است. از نتايج ديگر اين يروهش، جانشينى نيروى كار

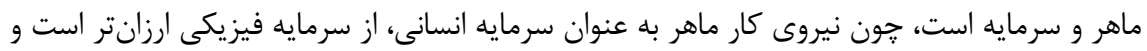
بنَّاه نيروى كار ماهر را جانشين سرمايه مى كند، يس تغيير فناورى اثر مثبت بر اشتغال دارد. رابرتس و و اسكوفياس' (99V) (19)، نشان مىدهند كه منحنى تقاضا براى نيروى كار ماهر و غيرماهر مىتواند متمايز

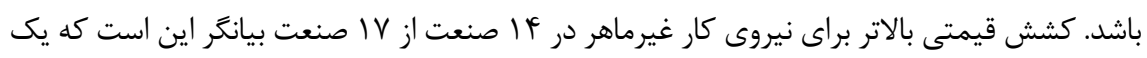

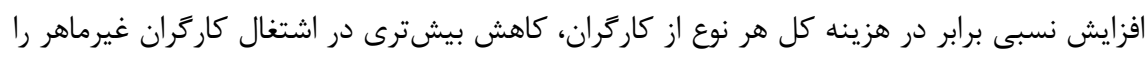

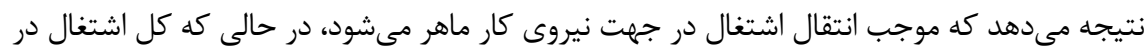

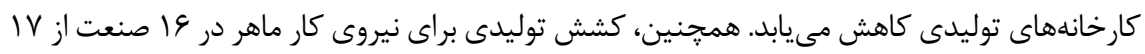
صنعت برابر يا بيشتر از كشش توليدى براى نيروى كار غيرماهر است. اين موضوع بيانكر آن است كه هـ با تغيير مقياس توليدى، اشتغال نيروى كار ماهر متناسب با توليد كارخانها (در بيشتر صنايع) تغيير مى كند، بلهورى كه با حركت به سمت كارخانهاى بزرگتر، اشتغال نيروى كار ماهر با يك نرخ رشد

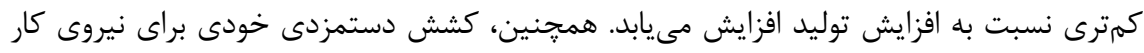

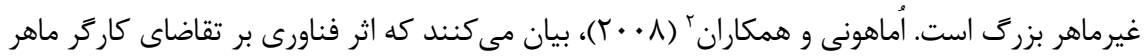

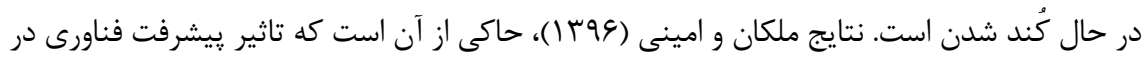
قالب شاخصهاى نسبت سرمايه تحقيقوتوسعه به ارزشافزوده و شاخص تركيبى كاربران رايانه و اينترنت

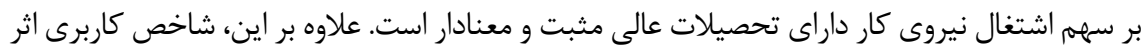

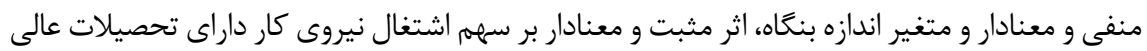
دارد. فرجادى و همكاران (99 ())، نشان مىدهند كه آزادسازى تجارى به افزايش سهم اشتغال نيروى

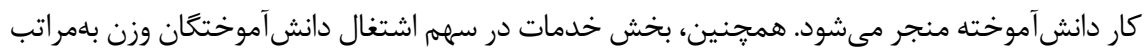
بيشترى نسبت به بخش صنعت دارد، و نسبت صادرات با فناورى بالا از كل صادرات بر سهمم اشتغال

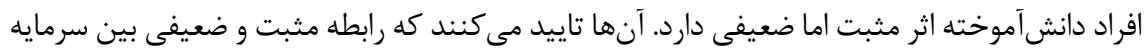

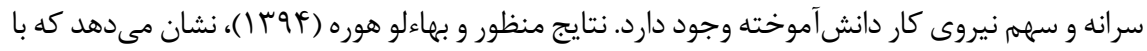
افزايش حداقل دستمزد، اشتغال نيروى كار ساده در همه بخشهاى توليدى شامل بخشهاى كشاورزى،

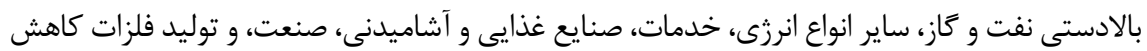
مى يابد. در حالى كه اشتغال نيروى كار ماهر در بخشىهاى كشاورزى و خدمات افزايش و در ساير بخشها 
كاهش مى يابد. صميمى و هزبر كيانى (سوس ())، نشان مى دهند كه فناورى اطلاعات و ارتباطات بر اشتغال صنايع كارخانهاى كشور (كدهاى جهاررقمى) اثر مثبت دارد، در حالى كه اثر اين شاخص در سطوح مهارتى نيروى كار متفاوت است. كفتنى است با ورود و ظهور اوليه ICT در يك بنگاه اقتصادى، به دليل نبود مهارت كافى نيروى كار حاضر، بهويزه كارگران ساده، بنكاهها مجبور به انجام تعديل نيروى كار خود

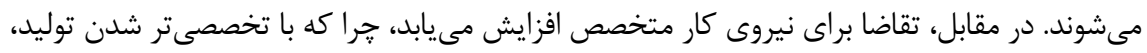
نياز بنكاهها به نيروهاى داراى تخصص در زمينه فناورى اطلاعات براى نصب، راهاندازى، برنامهريزى،

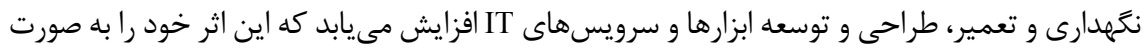

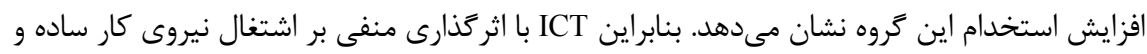

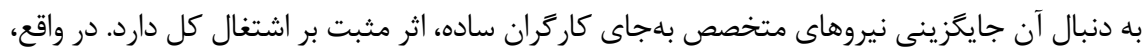

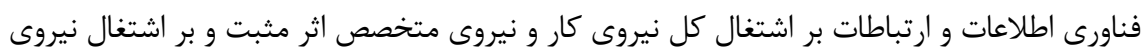

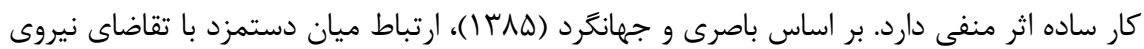

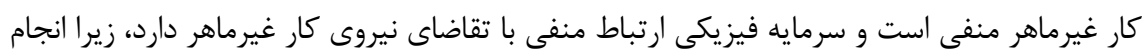

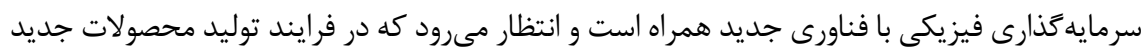
از نيروى كار ماهر و نه غيرماهر استفاده شود. تاثير بهرهورى بر تقاضاى نيروى كار غيرماهر نيز منفى

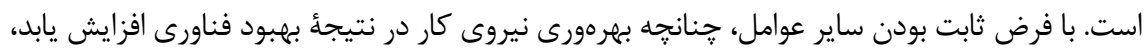

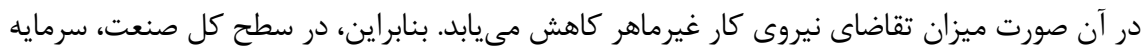

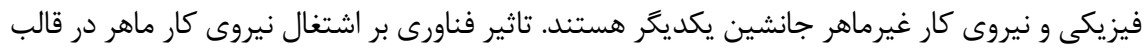

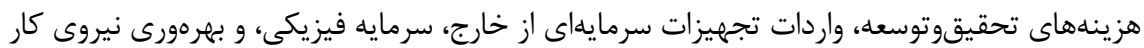

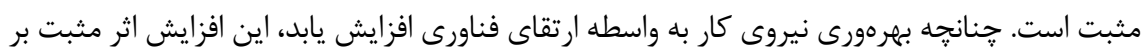

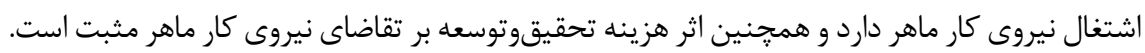

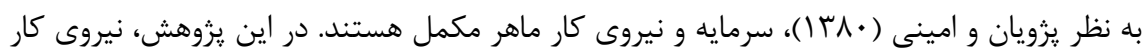

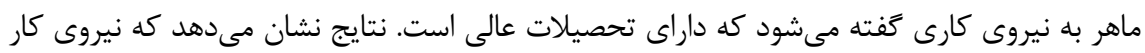
ماهر و سرمايه در تمامى بخشهاى توليدى و خدماتى مكمل هستند. بنابراين، بكاركيرى سياستهايى

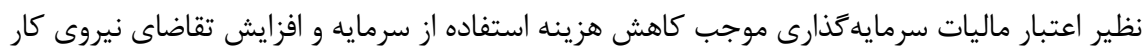
ماهر مىشود. در بخشهاى توليدى، نيروى كار ماهر و غيرماهر جانشين، و در بخش هاى خدماتى مكمل

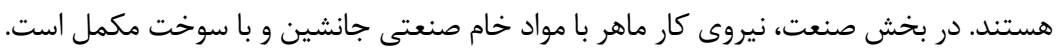

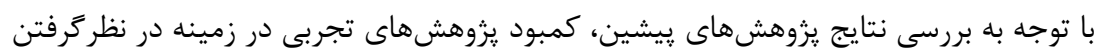


ناهمگَنى نيروى كار برحسب سطح سواد در ايران احساس مىشود و اجراى برخى سياستهاى بازار

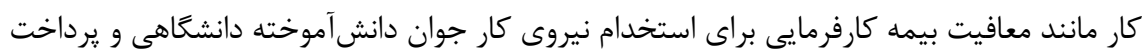

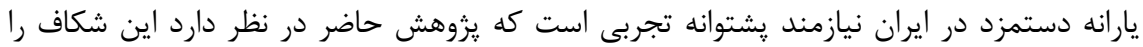
برطرف نمايد. افزون بر اين، اطلاع از تفاوتهاى بين كششهاى توليدى اشتغال برحسب سطح سواد

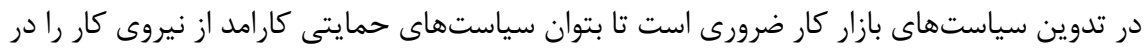
دوران ركود اجرا نمود. در اين راستا، دو فرضيه زير مورد آزمون تجربى قرار مى كيردي

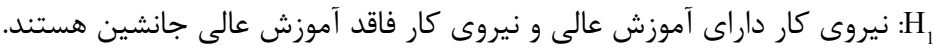

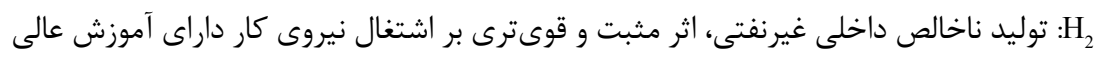
در مقايسه با نيروى كار فاقد آموزش عالى دارد. در رابطه با فرضيه H مى Hتوان جنين استدلال كرد كه در سال هاى اخير شاهد افزايش نرخ بيكارى

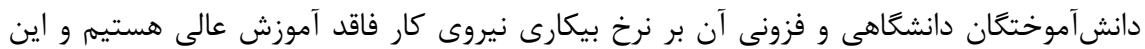
موضوع باعث مىشود دانشآموختخان دانشخاهى مجبور شوند مشاغل غير تخصصى را هم بريذيرند و در در صورت تاييد مطلب اشارهشده، مىتوان انتظار داشت نيروى كار دانشآموخته دانشعاهى جانشي مانشين افراد كمسواد شده باشد. در صورت تاييد فرضيه يادشده، اجراى سياستهاى يارانه دستمزد و معافيت حق مق مقيى بيمه سهم كارفرما براى استخدام دانشآموختگان دانشخاهى مىتواند به كاهش هزينه نسبى استفاده

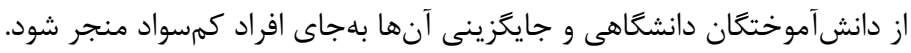

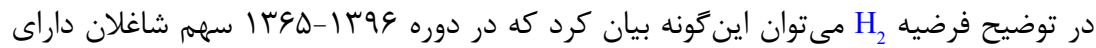
آموزش عالى افزايش قابلملاحظهاى داشته است و بر اساس اين، احتمال مىرود با يك رشد معين توليد، تقاضا براى نيروى كار داراى آموزش عالى بيشتر از نيروى كار فاقد آموزش عالى الى افزايش يابد.

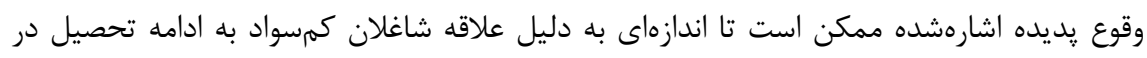
دانشگاهها و برخوردارى از دستمزدهاى بالاتر در فعاليتهاى اقتصادى باشد. تاييد فرضيه دوم به اين

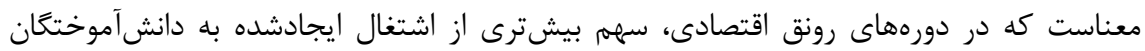
دانشَاهى اختصاص مىيابد و در دورههاى ركود، ريزش اشتغال دانشآموختخان دانشعاهى بيشتر

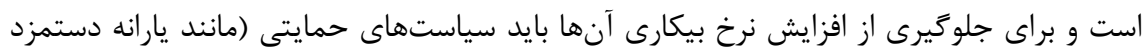

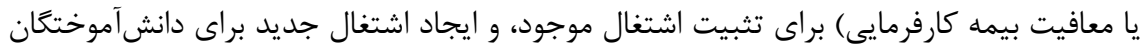
دانشخاهى اجرا شود. 


\section{روش رشناسى يخوهش}

دادهها

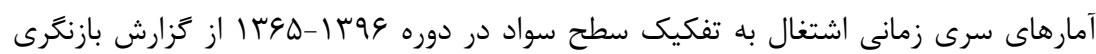

آمارهاى سرى زمانى شاخصهاى منتخب بازار كار استخراج مىشود كه توسط امور اقتصاد كلان

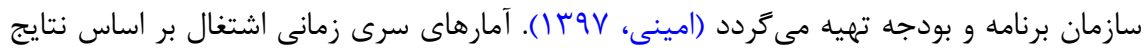

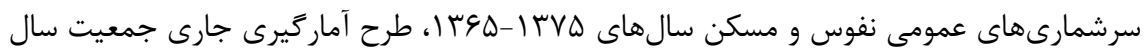
•

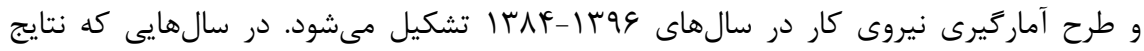
طرحهاى آماركيرى براى اشتغال موجود نبود، از روش درى درونيرى دابى مبتنى بر يكى متغير درونياب

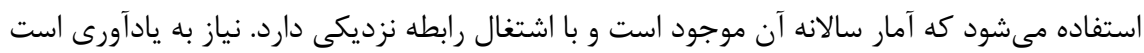

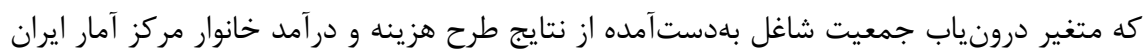
است'. در نهايت، آمارهاى دستمزدها به تفكيك سطح سواد توسط يزوهشكَران يزوهش حاضر، از

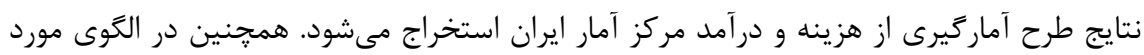

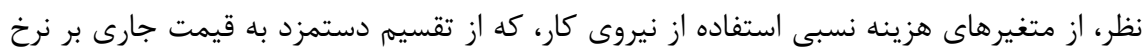

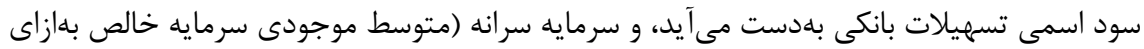

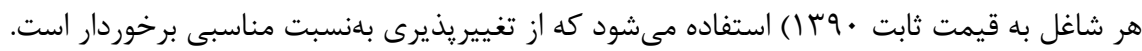

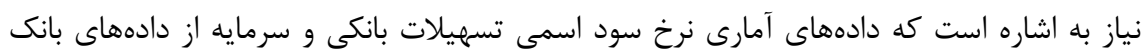

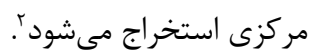

\section{معرفى روش بر آورد الكو}

روش گَشتاورهاى تعميميافته جّار جوبى را ارائه مى دهد كه به لحاظ محاسباتى روش سادهاى

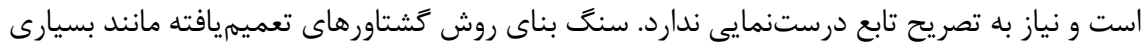
از روشهاى معروف تخمين در اقتصادسنجى، بر اطلاعاتى درباره شرايط گَتاورهاى جامعه قرار

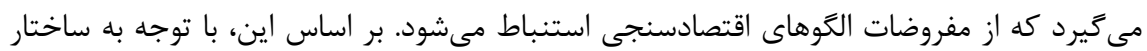
1. https://www.amar.org.ir

2. https://www.cbi.ir

3. Generalized Method of Moments (GMM) 
مدل يوياى تقاضاى نيروى كار كه به واسطه هزينههاى تعديل شكل مى

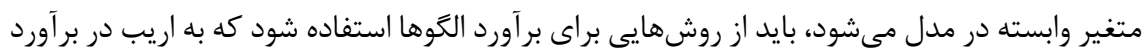

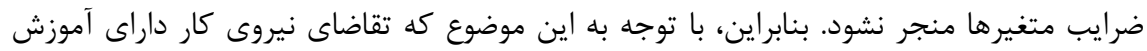
عالى و فاقد آموزش عالى از هم مجزا نيست و در يك سيستم اقتصادى بايد مورد بررسى قرار گيرد،

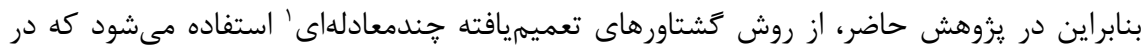
ادامه به شرح آن يرداخته مىشود.

\section{روش كَشتاورهاى تعميهريافته جندمعادلهاى}

در اين بخش، به روششناسى تخمين بيش از يك معادله به روش گَشتاورهاى تعميميافته

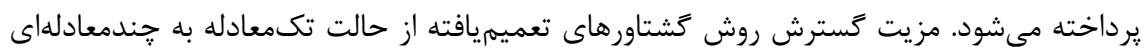

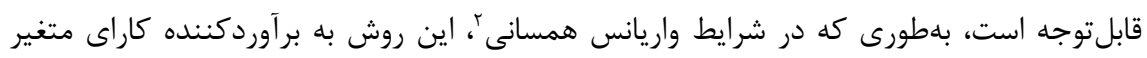

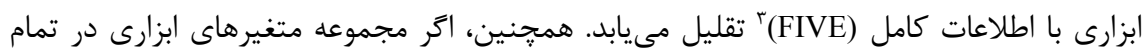

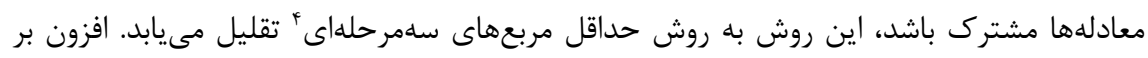

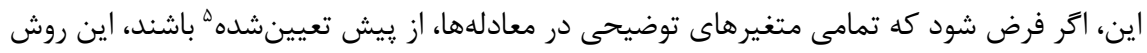

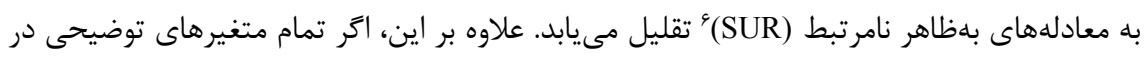

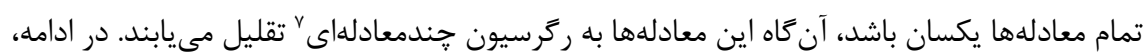

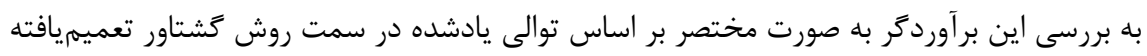

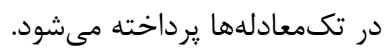

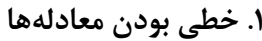

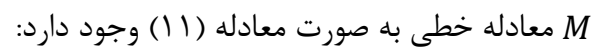

$\mathrm{y}_{\mathrm{im}}=\mathrm{z}_{\mathrm{im}}^{\prime} \delta_{\mathrm{m}}+\varepsilon_{\mathrm{im}}(\mathrm{m}=1,2, \ldots \ldots \mathrm{M} ; \mathrm{i}=1,2, \ldots \ldots, \mathrm{n})$

كه n، اندازه نمونه و Zim، بردار

1. Multiple Equation GMM

2. Conditional Homoscedasticity

3. Full-Information Instrumental Variables Estimator

4. Three-Stage Least Squares

5. Pre-Determined

6. Seemingly Unrelated Regressions

7. Multivariate Regression 
عبارت خطاى مشاهدهنايذير در M معادله است. نكتهاى كه وجود دارد، هيجگَنه فروضى در زمينه

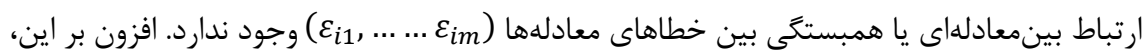
هيج گونه محدوديت از يِيش تعيينشدهاى روى ضرايب معادله هاى مختلف وجود ندارد.

\section{Y. متعامد بودن}

شرايط متعامد بودن براى M سيستم معادلهها، مجموع شرايط متعامد براى معادلههاى انفرادى است، بلهورى كه براى M معادله، هستند. بنابراين، شرايط متعامد بودن به صورت رابطه (T () بيان مىشودي: $\mathrm{E}\left(\mathrm{X}_{\mathrm{im}} \cdot \varepsilon_{\mathrm{im}}\right)=0 \quad(\mathrm{~m}=1,2, \ldots, \mathrm{M})$

كه در كل $\sum_{m} K_{m}$ شرايط متعامد بودن وجود دارد. در اين صورت:

$g_{i\left(\sum_{m=1}^{M} K_{m} \times 1\right)} \equiv\left[\begin{array}{c}X_{i 1} \cdot \varepsilon_{i 1} \\ \vdots \\ X_{i m} \cdot \varepsilon_{i m}\end{array}\right]$

بنابراين، تمام شرطهاى متعامد بودن به صورت فشرده به صورت رابطه (f ( ) قابل بيان است: $E\left(g_{i}\right)=0$

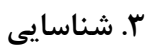

با توجه به شرايط متعامد بودن جندمعادلهاى، بر اساس اين، شرايط شناسايى به همان صورتى كه

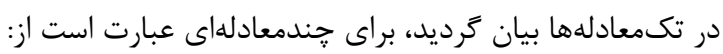

$g\left(W_{i} ; \delta\right) \equiv\left[\begin{array}{c}X_{i 1} \cdot\left(y_{i 1}-z_{i 1}^{\prime} \delta_{1}\right) \\ \vdots \\ X_{i m} \cdot\left(y_{i m}-z_{i m}^{\prime} \delta_{m}\right)\end{array}\right]$

بنابر اين، شرايط متعامد بودن مىتواند برابر 0 تم $0\left(g\left(W_{i} ; \delta\right)\right)$ باشد. بردار ضرايب قابلشناسايى $E\left[\left(g\left(W_{i} ; \delta\right)\right)\right]=$ هستند، اخر $\delta$ = $\delta$ تنها جواب سيستم معادلهها باشد: با استفاده از رابطه (Y (Y)، سمت جِ معادله را مىتوان به صورت رابطه (IV) بازنويسى كرد: 
$E\left[g\left(W_{i} ; \dot{\delta}\right)\right] \equiv\left[\begin{array}{c}E\left[X_{i 1} \cdot\left(y_{i 1}-z_{i 1}^{\prime} \delta_{1}\right)\right] \\ \vdots \\ E\left[X_{i M} \cdot\left(y_{i M}-z_{i M}^{\prime} \dot{\delta}_{M}\right)\right]\end{array}\right]=\left[\begin{array}{c}E\left(X_{i 1} \cdot y_{i 1}\right) \\ \vdots \\ E\left(X_{i M} \cdot y_{i M}\right)\end{array}\right]-\left[\begin{array}{c}E\left(X_{i 1} z_{i 1}^{\prime}\right) \dot{\delta}_{1} \\ \vdots \\ E\left(X_{i M} z_{i M}^{\prime}\right) \grave{\delta}_{M}\end{array}\right]=$ $\left[\begin{array}{c}E\left(X_{i 1} \cdot y_{i 1}\right) \\ \vdots \\ E\left(X_{i M} \cdot y_{i M}\right)\end{array}\right]-\left[\begin{array}{ccc}E\left(X_{i 1} z_{i 1}^{\prime}\right) & \cdot & \cdot \\ \cdot & \ddots & \cdot \\ \cdot & \cdot & E\left(X_{i M} z_{i M}^{\prime}\right)\end{array}\right]\left[\begin{array}{c}\delta_{1} \\ \vdots \\ \delta_{M}\end{array}\right] \equiv \sigma_{X y}-\sum_{X Z} \delta$

$$
\sigma_{X y} \equiv\left[\begin{array}{c}
E\left(X_{i 1} \cdot y_{i 1}\right) \\
\vdots \\
E\left(X_{i M} \cdot y_{i M}\right)
\end{array}\right], \sum_{X z} \equiv\left[\begin{array}{ccc}
E\left(X_{i 1} z_{i 1}^{\prime}\right) & \cdot & \cdot \\
\cdot & \ddots & \cdot \\
\cdot & \cdot & E\left(X_{i M} z_{i M}^{\prime}\right)
\end{array}\right]
$$

بر اساس اين، در اين سيستم معادلهها كُ مىتواند به صورت رابطه (1) بلهدست آيد: $\sigma_{X y}=\sum_{X z} \cdot \delta$

اين رابطه دقيقاً با معادلهُ بهدستآمده از حالت تكمعادله يكسان است. با توجه به بحث شناسايى

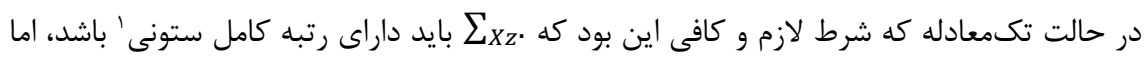
از آنجايى كه در جندمعادلهای .

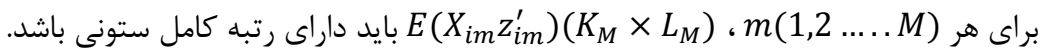

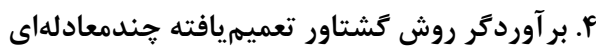

3
3
3
3
3
3
3
3
3
3
3
3

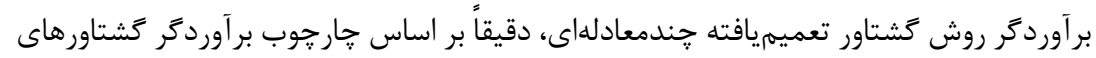

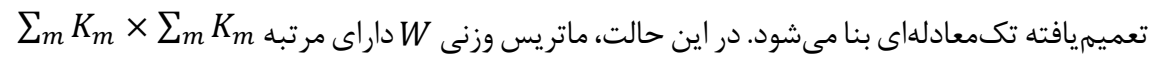

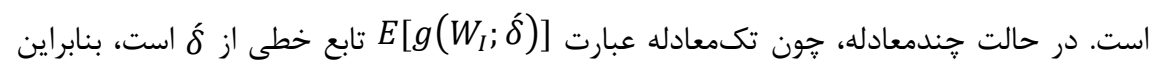

$$
\begin{aligned}
g_{n\left(\sum_{m=1}^{M} K_{m} \times 1\right)}(\dot{\delta}) & =\left[\begin{array}{c}
\frac{1}{n} \sum_{i=1}^{n} X_{i 1} \cdot\left(y_{i 1}-z_{i 1}^{\prime} \dot{\delta}_{1}\right) \\
\vdots \\
\frac{1}{n} \sum_{i=1}^{n} X_{i M} \cdot\left(y_{i M}-z_{i M}^{\prime} \dot{\delta}_{M}\right)
\end{array}\right]=\left[\begin{array}{c}
\frac{1}{n} \sum_{i=1}^{n} X_{i 1} y_{i 1} \\
\vdots \\
\frac{1}{n} \sum_{i=1}^{n} X_{i M} y_{i M}
\end{array}\right]-\left[\begin{array}{c}
\frac{1}{n} \sum_{i=1}^{n} X_{i 1} z_{i 1}^{\prime} \dot{\delta}_{1} \\
\vdots \\
\frac{1}{n} \sum_{i=1}^{n} X_{i M} z_{i M}^{\prime} \dot{\delta}_{M}
\end{array}\right] \\
& =\left[\begin{array}{c}
\frac{1}{n} \sum_{i=1}^{n} X_{i 1} y_{i 1} \\
\vdots \\
\frac{1}{n} \sum_{i=1}^{n} X_{i M} y_{i M}
\end{array}\right]-\left[\begin{array}{ccc}
\frac{1}{n} \sum_{i=1}^{n} X_{i 1} z_{i 1}^{\prime} & \cdot \\
\cdot & \ddots & \cdot \\
\cdot & \cdot & \frac{1}{n} \sum_{i=1}^{n} X_{i M} z_{i M}^{\prime}
\end{array}\right]\left[\begin{array}{c}
\delta_{1} \\
\vdots \\
\delta_{M}
\end{array}\right] \equiv s_{X y}-S_{X z} \delta
\end{aligned}
$$




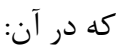

$S_{X y}=\left[\begin{array}{l}\frac{1}{n} \sum_{i=1}^{n} X_{i 1} y_{i 1} \\ \vdots \\ \frac{1}{n} \sum_{i=1}^{n} X_{i M} y_{i M}\end{array}\right], S_{X z}=\left[\begin{array}{ccc}\frac{1}{n} \sum_{i=1}^{n} X_{i 1} z_{i 1}^{\prime} & . & \\ . & \ddots & . \\ . & \cdot & \frac{1}{n} \sum_{i=1}^{n} X_{i M} z_{i M}^{\prime}\end{array}\right]$

بنابراين، برآوردكر كشتاور تعميميافته קندمعادلهاى عبارت است از:

$\delta(\dot{W})_{G M M}=\left(S_{X Z}^{\prime} \dot{W} S_{X Z}\right)^{-1} S_{X Z}^{\prime} \dot{W} S_{X y}$

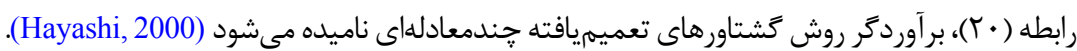

بر آورد الكَو و تجزيهو تحليل يافتهها

در اين بخش، به تصريح الكو، برآورد، تفسير و تحليل نتايج حاصل از آن، و در نهايت ارائه

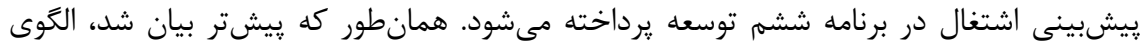

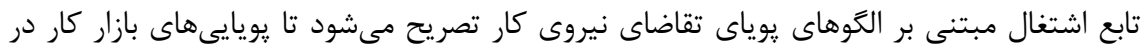

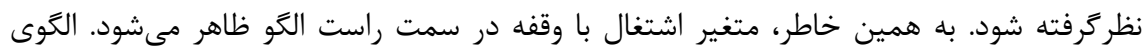

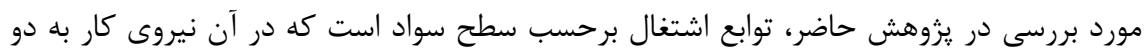

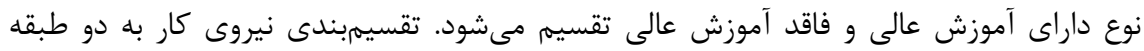

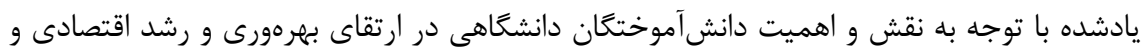

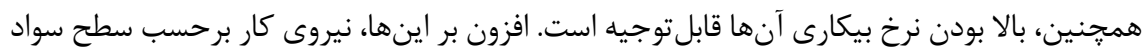

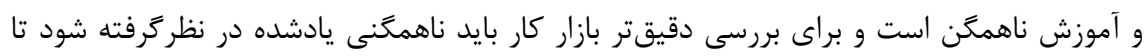

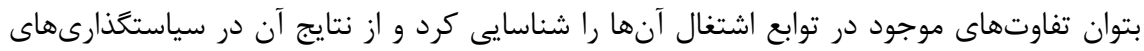

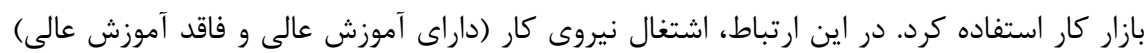

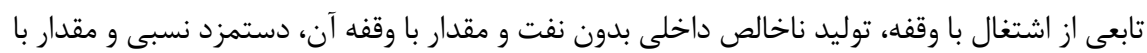

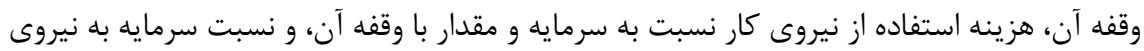

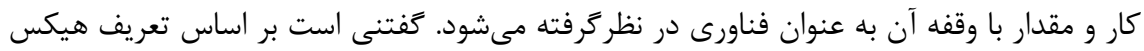

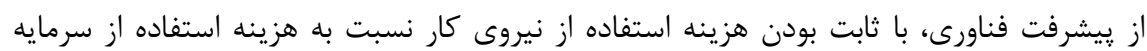

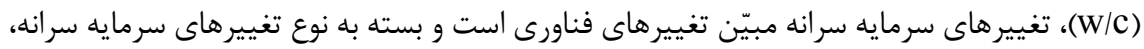


״يشرفت فناورى ميىتواند كاراندوز، سرمايهاندوز يا خنثى باشد (Salvatore, 1987). در ضمن، دليل استفاده از توليد ناخالص داخلى بدون نفت بهجاى توليد ناخالص داخلى آن آن است كه بخش نفت نفت كمرتر

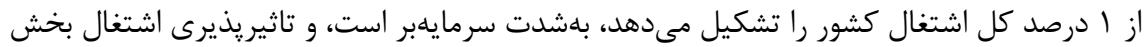
نفت از توليد ناجيز است. از طرف ديخر، ارزشافزوده بخش نفت يرنوسان و بلهدت تحت تاثير شرايط بازار جهانى نفت و تحريمهاى بينالمللى است. به دليل دولتى بودن ساختار مالكيت در بخش نفت، اشتغال در اين بخش كمتر از متغيرهاى اقتصادى تاثير مىيذيرد و بيشتر تحت تاثير تصميمهاى

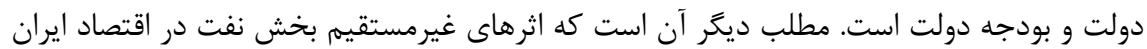
از راه ارزشافزوده ساير بخشهاى اقتصادى در قالب توليد ناخالص داخلى غيرنفتى لحاظ مىشود. بر اساس اين، فرم قابلتخمين الخوى توابع اشتغال برحسب سطح سواد به صورت رابطه (Iآ است است:

$$
\begin{gathered}
\log L_{j . t}=\mu_{j} \log L_{j . t-1}+a_{0 j} \log Q_{t}+a_{1 j} \log Q_{t-1}+\sum_{i \neq j} \gamma_{0 i} \log \left(\frac{w_{j}}{w_{i}}\right)_{t} \\
+\sum_{i \neq j} \gamma_{1 i} \log \left(\frac{w_{j}}{w_{i}}\right)_{t-1}+\beta_{0 j} \log \left(\frac{w}{c}\right)_{t}+\beta_{1 j} \log \left(\frac{w}{c}\right)_{t-1(Y))} \\
+\theta_{0 j} \log \left(K_{j} / L_{j}\right)_{t}+\theta_{1 j} \log \left(K_{j} / L_{j}\right)_{t-1}+\delta_{j}+u_{j, t} \\
t=1.2 \ldots . T . j=1.2
\end{gathered}
$$

كه در آن L اشتغال، Q به نيروى كار نوع i، w/c هزينه استفاده از نيروى كار نسبت به هزينه استفاده از سرمايه، L/L سرمايه

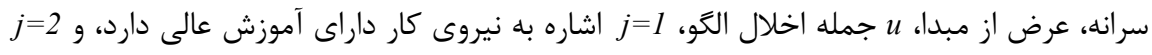

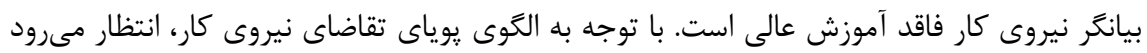
ضريب اشتغال با وقفه بين صفر و يك باشد. همجنين، انتظار مىرود در رابطه (Iا)، جمع جبرى ضرايب توليد و مقدار با وقفه آن مثبت باشد كه بيانكر كشش توليد اشتغال در كوتاهدت است. در

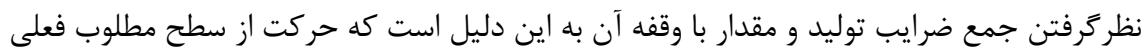

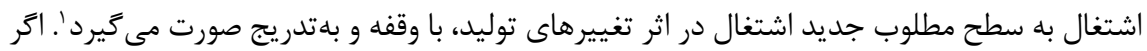

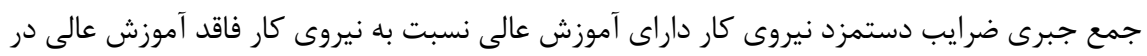

ا. در مورد ساير ضرايب نيز تفسير به همين ترتيب قابل ارائه است، يعنى حركت از سطح مطلوب فعلى اشتغال

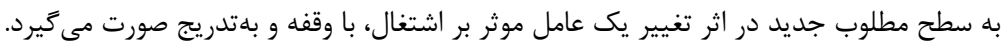


تابع اشتغال نيروى كار داراى آموزش عالى، و همجنين اكر ضريب دستمزد نيروى كار فاقد آموزش آمار

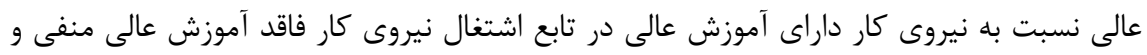

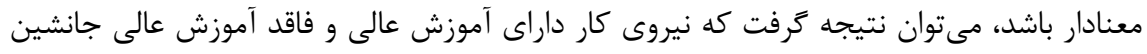

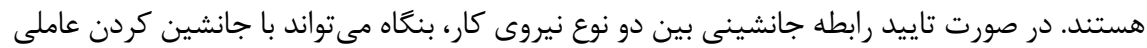

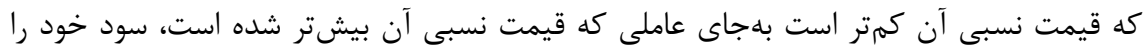

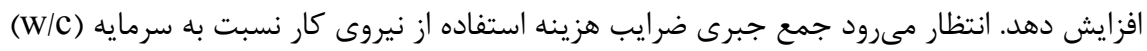

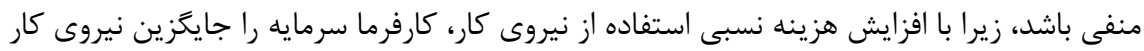

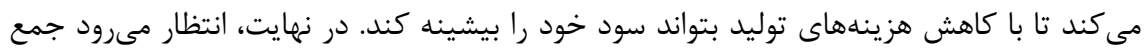

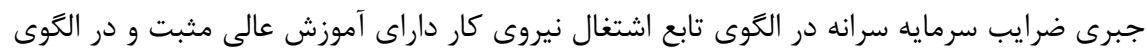

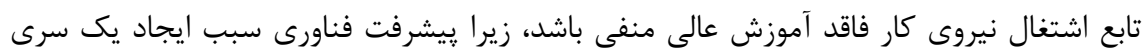

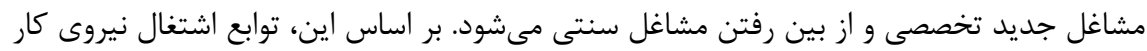

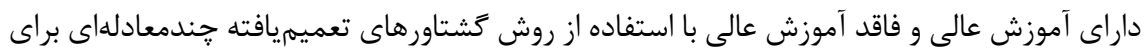

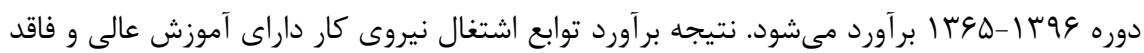
آموزش عالى با استفاده از نرمافزار جدول ا: نتايج بر آورد توابع اشتغال برحسب سطح سواد به روش گثتاورهاى تعميميافته جندمعادلهاى

\begin{tabular}{|c|c|c|c|c|}
\hline $\begin{array}{l}\text { احتمال } \\
\text { (Prob) }\end{array}$ & انحراف & 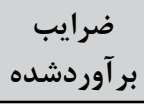 & 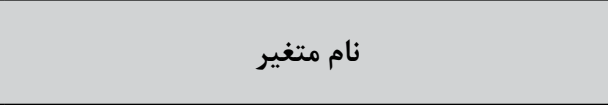 & تفكيك \\
\hline$\cdot / \cdots$ & $\cdot / T V$ & $-\mu / r \Delta$ & عرض از مبدا تابع اشتغال نيروى كار داراى آموزش عالى & \multirow{9}{*}{ تابع اشتغال } \\
\hline$\cdot / \cdot$ & $\cdot / \cdot r$ & $\cdot|\mathrm{V}|$ & لكاريتم اشتغال نيروى كار داراى آموزش عالى با يك وقفه & \\
\hline$\cdot 1 \cdots$ & $\cdot 1 \cdot 4$ & • & لكَاريتم توليد ناخالص داخلى غيرنفتى & \\
\hline$\cdot / \cdot \vee V$ & $\cdot / \cdot r$ & $-\cdot 119$ & 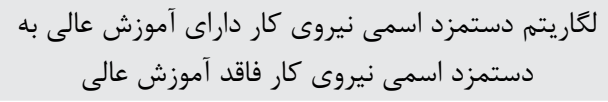 & \\
\hline$\cdot 1 \cdot$ & $\cdot / \cdot r$ & $-\cdot 119$ & لكًاريتهم دستمزد نسبت به نرخ سود تسهيلات & \\
\hline$\cdot / \cdots$ & $\cdot / \cdot r$ & $\cdot / 14$ & لكَاريتم دستمزد نسبت به نرخ سود تسهيلات با يك وقفه & \\
\hline$\cdot \cdots$ & $.1 \cdot 9$ & $-1 / 4$. & لكَاريتم سرمايه سرانه (نسبت موجودى سر مايهبه تعداد شاغلان) & \\
\hline \multirow[t]{2}{*}{$\cdot 1 \cdot$} & $\cdot / \cdot v$ & $1 / 4 T$ & لحاريتم سرمايه سرانه با يك وقفه & \\
\hline &.$/ 990$ & & قدرت تشريح تعديلشده & \\
\hline
\end{tabular}




\begin{tabular}{|c|c|c|c|c|}
\hline $\begin{array}{l}\text { احتمال } \\
\text { (Prob) }\end{array}$ & انحراف & 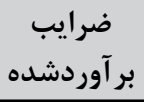 & 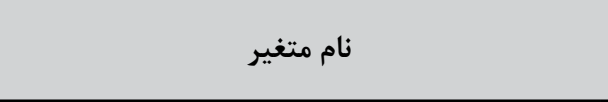 & 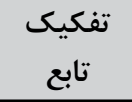 \\
\hline$\cdot \cdots$ & $\cdot 190$ & $F / l f$ & عرض از مبدا تابع اشتغال نيروى كار فاقد آموزش عالى & \multirow{9}{*}{ نابع اشتغال } \\
\hline$\cdot \cdots$ & $\cdot 1 \cdot V$ & $\cdot / \mu \Lambda$ & لكاريتم اشتغال نيروى كار فاقد آموزش عالى با يك وقفه & \\
\hline$\cdot / \cdot$ & $\cdot 1 \cdot r$ & $\cdot|4|$ & لكاريتم توليد ناخالص داخلى غيرنفتى & \\
\hline 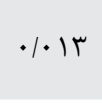 & $.1 \cdot 9$ & $-\cdot / 10$ & لكاريتم دستمزد نيروى كار فاقد آموزش عالى به نيروى آموزى عالى & \\
\hline$\cdot / \cdot$ & $\cdot 1 \cdot r$ & $-\cdot 119$ & لحًاريتم دستمزد نسبت به نرخ سود تسهيلات & \\
\hline$\cdot 1 \cdot$ & $\cdot / \cdot r$ & $\cdot / 1 r$ & لكاريتم دستمزد نسبت به نرخ سود تسهيلات با يك وقفه & \\
\hline$\cdot / \cdot$ & $\cdot 1 \cdot 9$ & $-\cdot / \mathrm{r}$ & ل لكًاريتم سرمايه سرانه & \\
\hline \multirow[t]{2}{*}{$\cdot / \cdots$} & $\cdot 1 \cdot 1$ & $\cdot|4|$ & لكًاريتم سرمايه سرانه با يك وقفه & \\
\hline & $\cdot / 9 \wedge \mathrm{V}$ & & قدرت تشريح تعديلشده & \\
\hline \multicolumn{3}{|c|}{$1 / 9 \mu * 1 \cdot \wedge(-\vee)$} & دترمينان كوواريانس يسماندها & \\
\hline \multicolumn{3}{|c|}{$\cdot / T T \Delta$} & 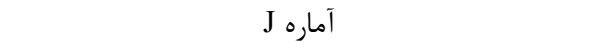 & \\
\hline
\end{tabular}

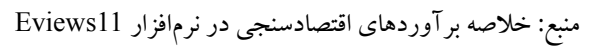

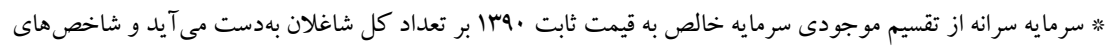

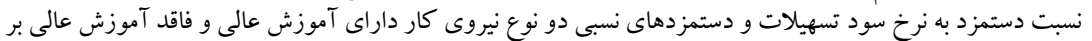

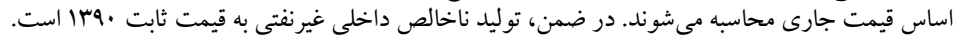

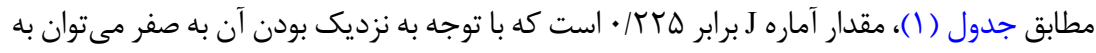

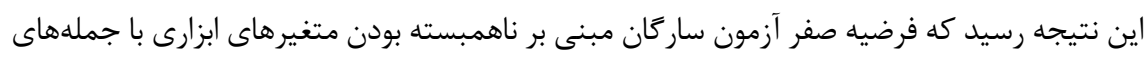

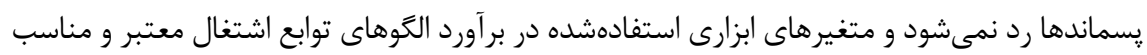

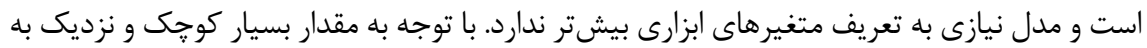

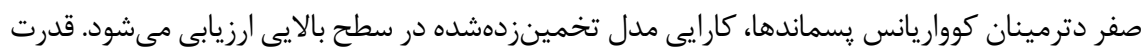

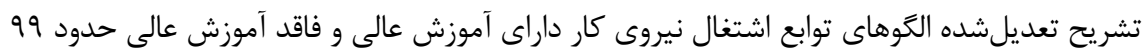

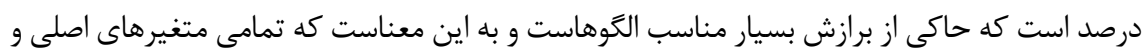

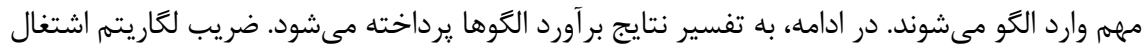

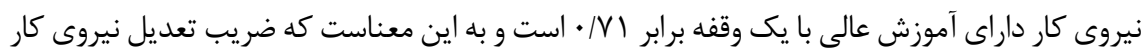

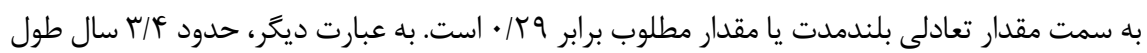


مى كشد تا سطح موجود اشتغال نيروى كار داراى آموزش عالى به سطح مطلوب خود برسد.

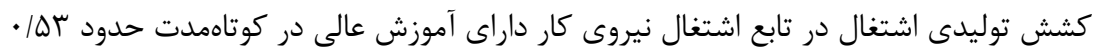

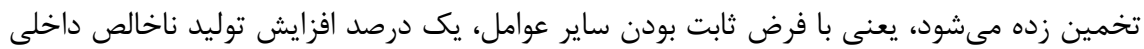

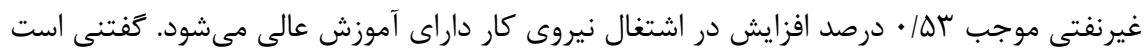

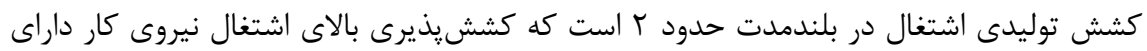

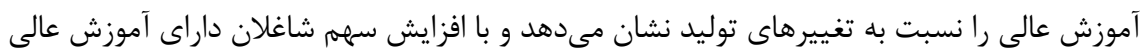

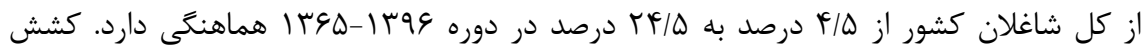

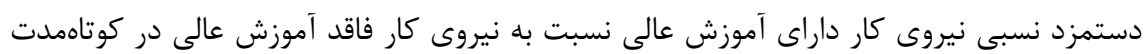

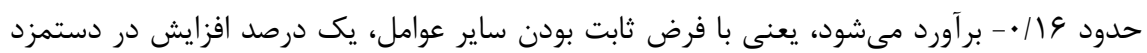

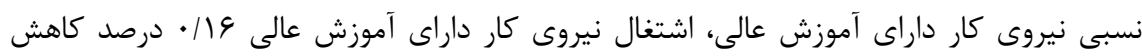

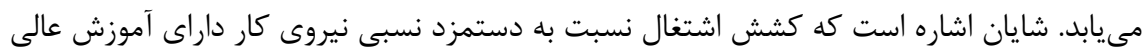
در بلندمدت حدود فه|•-- تخمين زده مىشود و اين نتيجه به اين معناست كه نيروى كار داراى آموزش عالى و نيروى كار فاقد آموزش عالى دو عامل جانشين در فرايند توليد هستند.

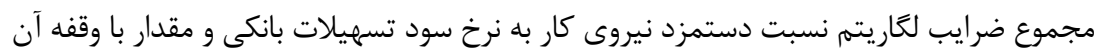

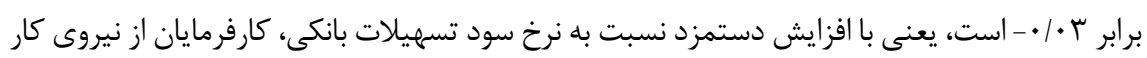

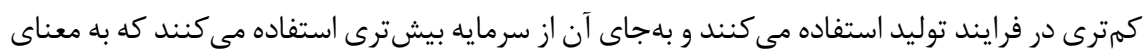
جانشين بودن كار و سرمايه است. كفتنى است كه كشش اشتغال نسبت به هزينه استفاده از نيروى كار نسبت به سرمايه در بلندمدت حدود • // •- است و در نتيجه، رابطه جانشينى بين كار و سرمايه

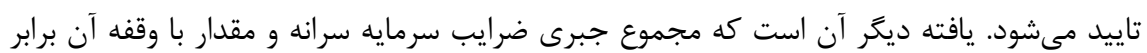

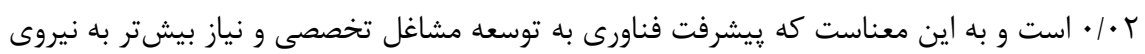

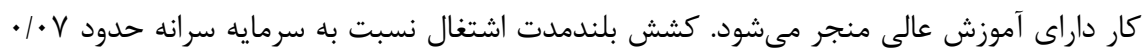

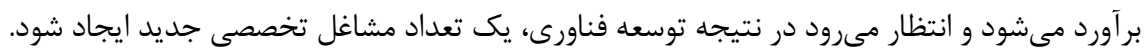

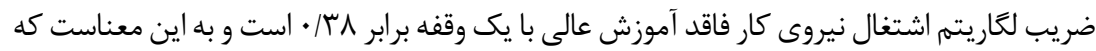
ضريب تعديل نيروى كار فاقد آموزش عالى به سمت مقدار مطلوب آن برابر باع|• است، يعنى

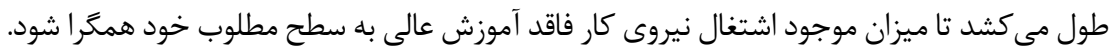

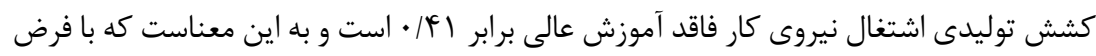

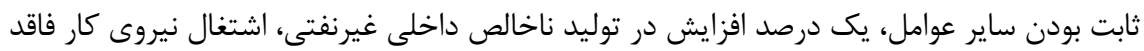




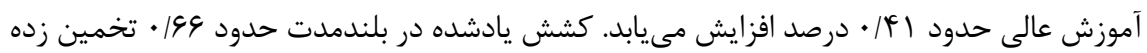

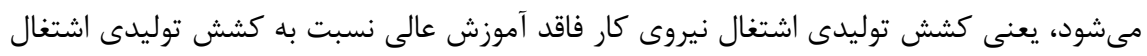

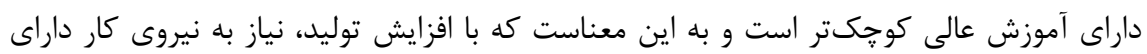

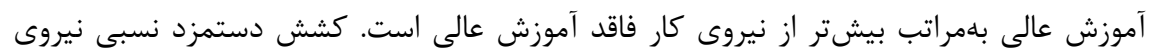

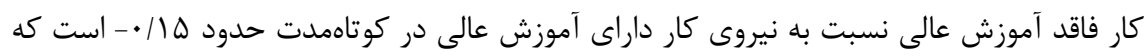

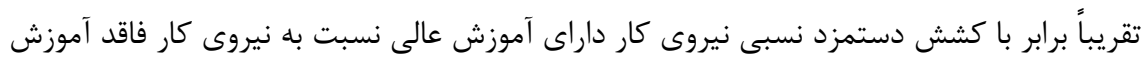

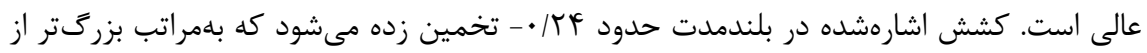

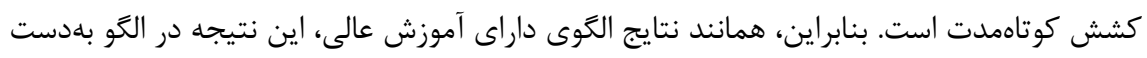

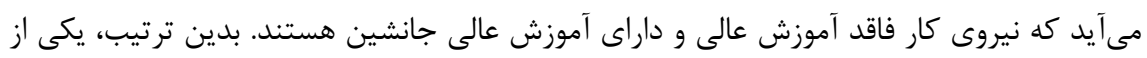

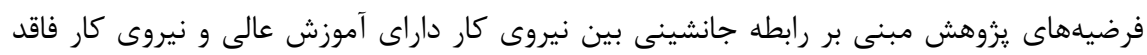

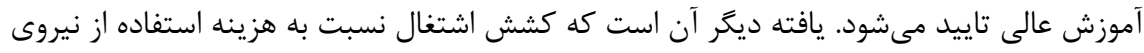

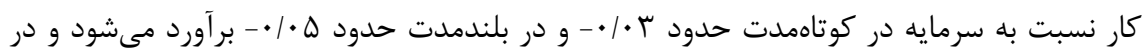

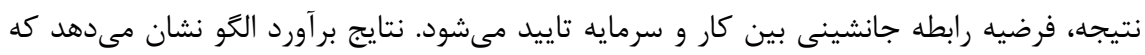

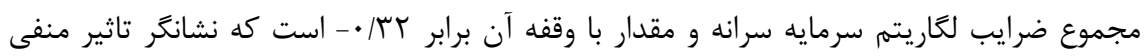

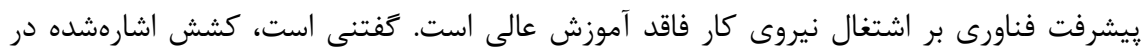

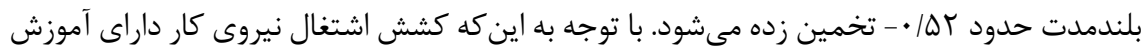

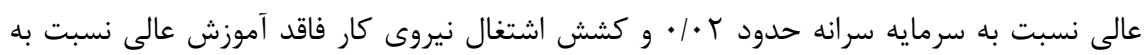

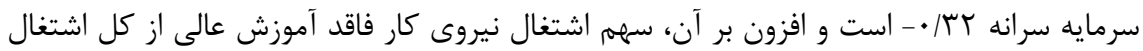
كشور بالاتر است، در نتيجه توسعه فناورى بر كل اشتغال كشور اثر أر منفى دارد.'

\section{ييشبينى اشتغال در برنامه ششم توسعه}

در اين بخش، با استفاده از نتايج الكوى برآوردى، ميزان اشتغال كشور در قالب دو كزينه ادامه روند

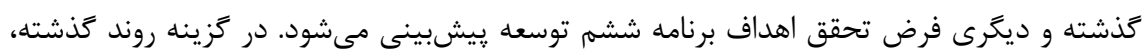

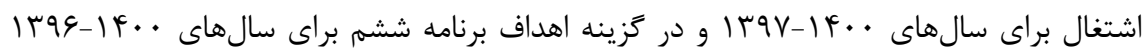

ا. متغيرهاى درجه باز بودن اقتصاد و سهم ارزشافزوده خدمات از توليد ناخالص داخلى مورد بررسى قرار كرفتند، ولى به دليل معنادار نبودن وارد الكَ نشدند. 


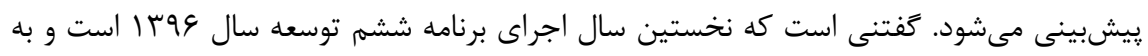

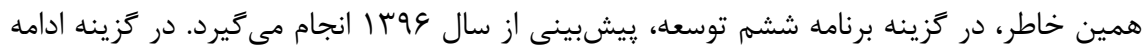

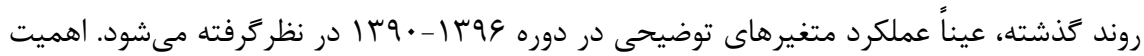

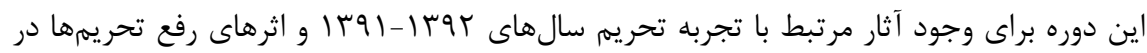

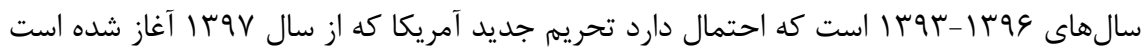

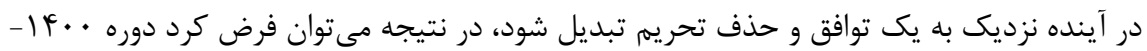

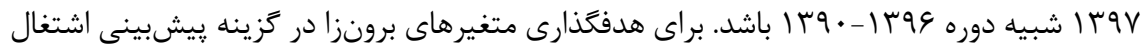

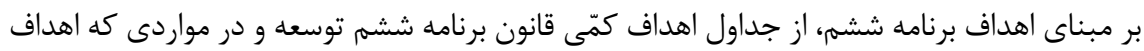
كمّى وجود ندارد از مستندها و رويكردهاى برنامه ششم توسعه و نظرهاى كارشناسى استفاده مى شىود.

\section{هدفحذارى متغيرهاى برونزاى تاثير حذار بر اشتغال برحسب سطح سواد}

نرخ رشد متغيرهاى برونزاى الكَى اشتغال برحسب سطح سواد بر مبناى ادامه روند عملكرد

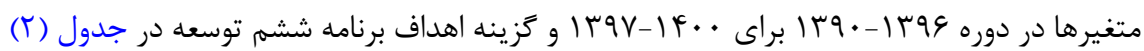

\section{جدول r: هدفكذارى متغيرهاى مستقل توابع اشتغال براى بيشينى اشتغال در آينده}

\begin{tabular}{|c|c|c|}
\hline اداملَ روند كذشته & برنامه ششم & 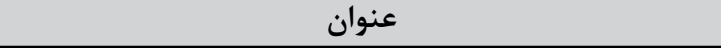 \\
\hline $1 / 4$ & $\Lambda / r$ & 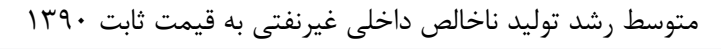 \\
\hline$-\cdot / \mu$ & $\cdot / \Delta$ & متوسط رشد نسبت دستمزد نيروى كار فاقد آموزش عالى به دستمزد \\
\hline$\cdot / \mu$ & $-\cdot / \Delta$ & 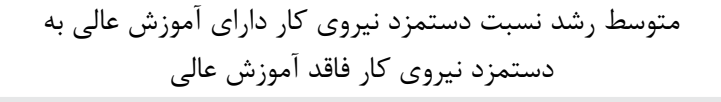 \\
\hline$r \cdot / V$ & $r \cdot 19$ & متوسط رشد هزينه استفاده از نيروى كار نسبت به سرمايه در سطح \\
\hline$-\cdot / V$ & $r / T$ & متوسط رشد سرمايه سرانه \\
\hline
\end{tabular}




\section{بر رسى خوبى برازش و قدرت يِشبينى الكَى بر آورد اشتغال به تفكيك سطح سواد}

الكَوهاى توابع اشتغال داراى آموزش عالى و فاقد آموزش عالى بلهترتيب با قدرت توضيحدهندگى

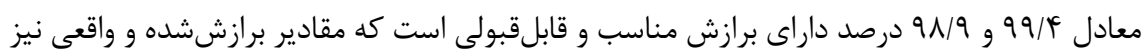
به يكديكر نزديك هستند. همجنين، بايد خاطرنشان كرد كه معيار RMSE براى اين دو الكو بهترتيب

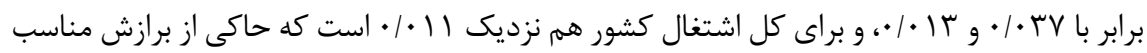
الكوهاست.

يس از آن كه ميزان تطابق مقادير برآوردشده و واقعى مورد بررسى قرار گرفت، بايد از الكوى

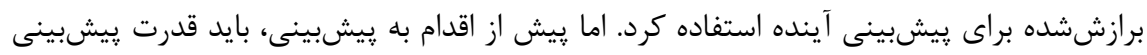

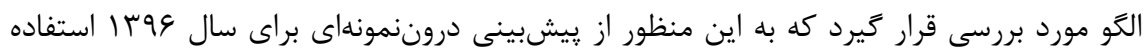

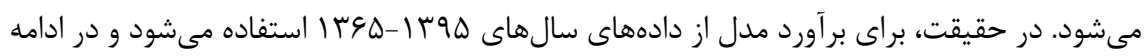
به يِيشبينى يك كام جلوتر' اقدام مىشود كه در اينجا معادل يكى سال است. با توجه به به اينكه

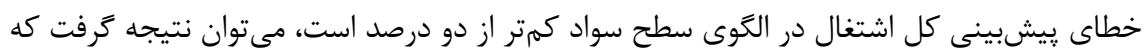

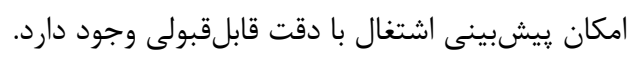

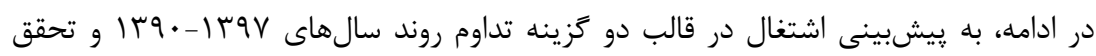

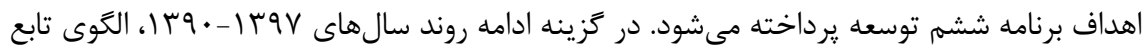

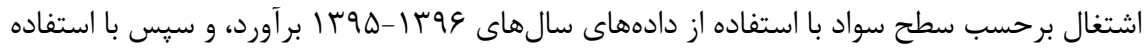

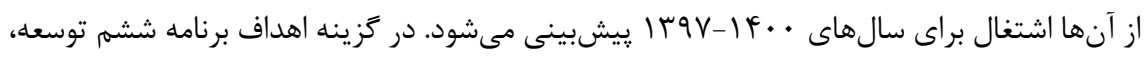

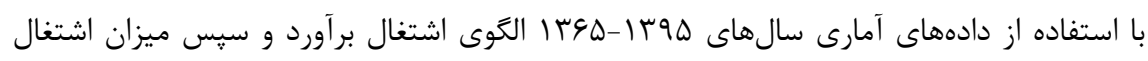

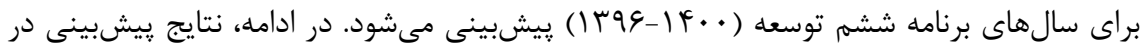

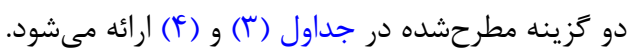




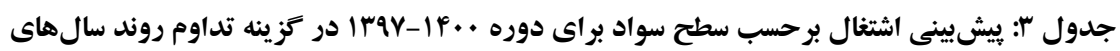

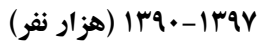

\begin{tabular}{|c|c|c|c|c|}
\hline \multirow{2}{*}{ 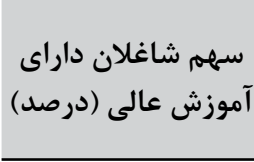 } & \multicolumn{3}{|c|}{ تعداد شاغلان به تفكيك سطح سواد (هزار نفر) } & \multirow[b]{2}{*}{ سال } \\
\hline & كل اشتغال كشور & $\begin{array}{l}\text { فاقد آموزش عالى } \\
\end{array}$ & داراى آموزش عالى & \\
\hline$T F / D$ & rmrvq & IVGYG & $\Delta V H T$ & 1499 \\
\hline$r F / q$ & TFIOA & $11 \mid k q$ & $4 . .9$ & $\mid f \ldots$ \\
\hline .1 .9 & 190 & ITE & 99 & 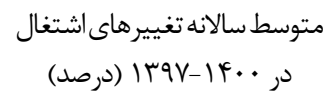 \\
\hline צ & $\cdot \mid \Lambda$ & $\cdot / \mathrm{V}$ & $1 / \pi$ & 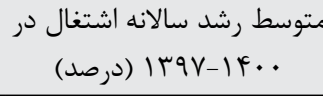 \\
\hline
\end{tabular}

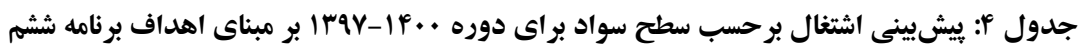
توسعه (هزار نفر ـ درصد)

\begin{tabular}{|c|c|c|c|c|}
\hline \multirow[b]{2}{*}{ سموزشم شاغلان داراى } & \multicolumn{3}{|c|}{ تعداد شاغلان به تفكيك سطح سواد (هزار نفر) } & \multirow[b]{2}{*}{ 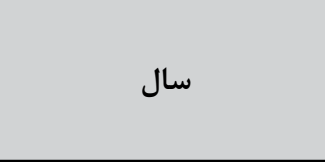 } \\
\hline & كل اشتغال كشور & فاقد آموزش عالى & داراى آموزش عالى & \\
\hline r & $r T \Delta \wedge \Lambda$ & IVTFI & $\Delta M F V$ & $1 \% 9 \Delta$ \\
\hline$T V / T$ & 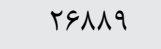 & $19 \Delta \& F$ & VKTD & $1 f \ldots$ \\
\hline$\cdot 1199$ & $\Lambda \varepsilon$. & fQF & raq & متوسط سالانه تغييرهاى اشتغال \\
\hline$r / \Delta V$ & $r / \Delta$ & $r / 9$ & $9 / 0$ & 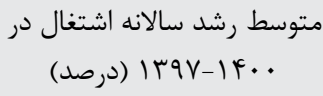 \\
\hline
\end{tabular}

تحليل نتايج بيشبينى اشتغال در خار خوب كزينهاى مختلف

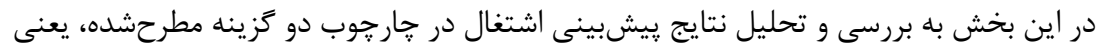

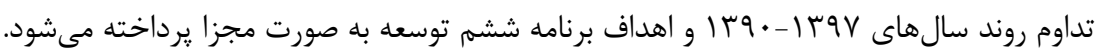




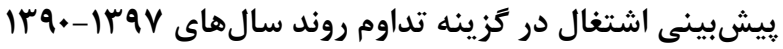

بر اساس اهداف تعيينشده براى متغيرهاى مستقل تابع اشتغال برحسب سواد، ميزان متوسط .

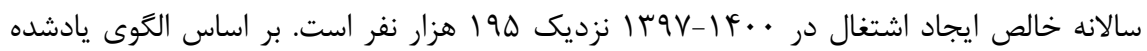

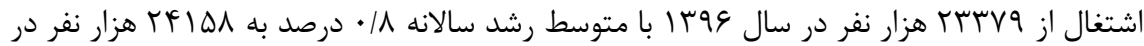
سال · · f افزايش مىيابد. كفتنى است كه بر اساس الكوى شاغلان داراى آموزش عالى، كل شاغلان

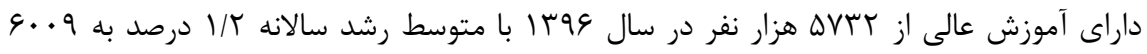

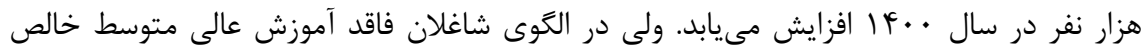

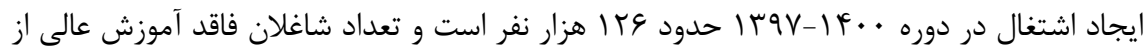
رقم |

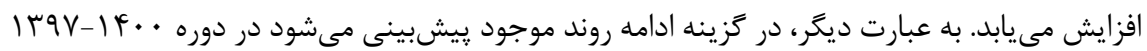

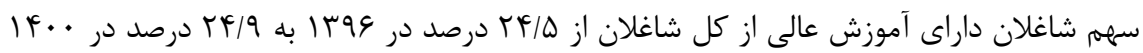

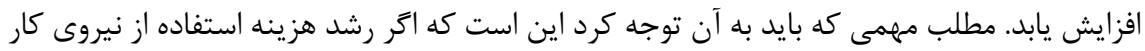

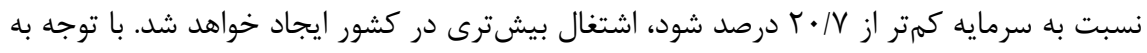

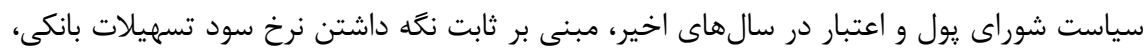

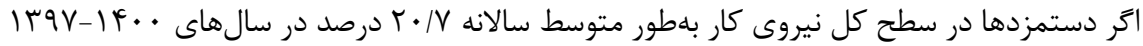

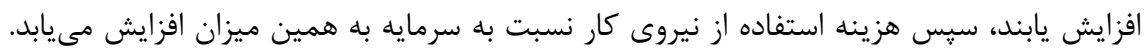

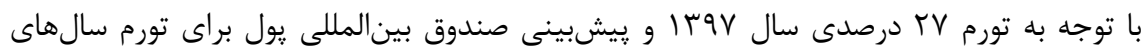

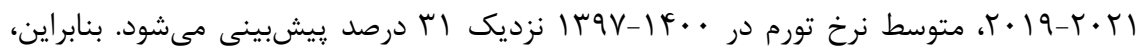

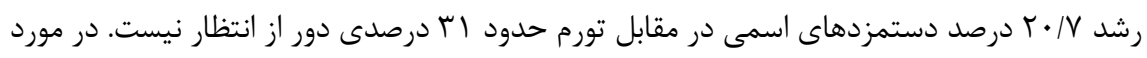

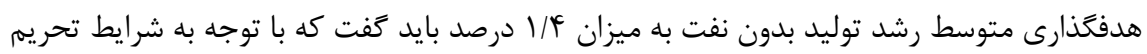

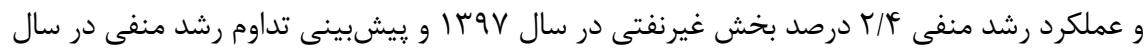

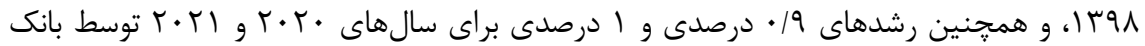
جهانى، نمىتوان هدفگذارى بالاتر از \&/1 درصد را در نظر كرفت. براى هدفكذارى رشد سرمايه سرانه به ميزان V/• •- درصد در سال بايد كفت تنزل شديدتر آن كمتر محتمل است، زيرا در دوران تحريم

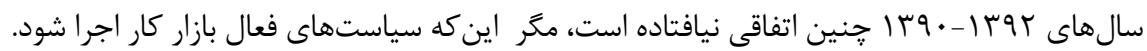
افزون بر اين، لازم است از توسعه بنكاههاى خرد و كوخى حمايت شود كه در آنها متوسط سرمايه 
بهازاى هر شاغل كوجىكتر است، تا سرمايه سرانه سريعتر كاهش يابد. البته همراه با اين سياست،

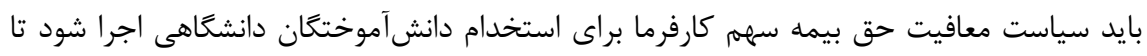

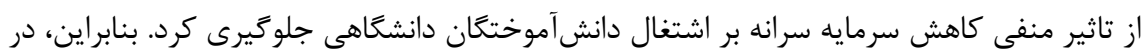

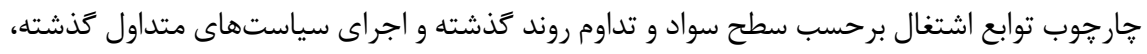

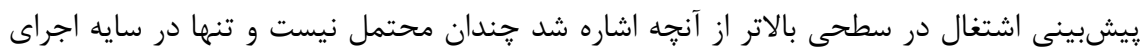

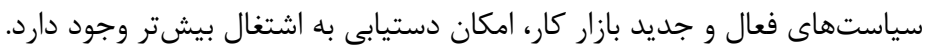

\section{يِيشبينى اشتغال در كزينه اهداف برنامه ششم توسعه}

بر اساس اهداف تعيينشده براى متغيرهاى مستقل توابع اشتغال برحسب سواد، ميزان متوسط

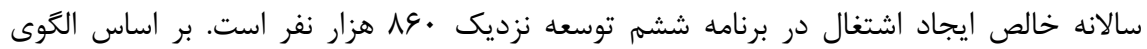

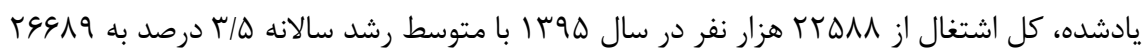

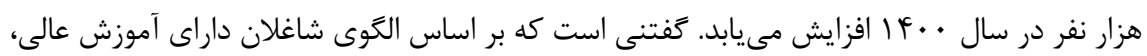

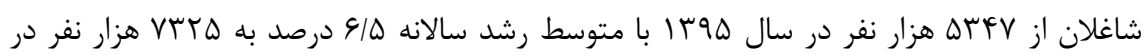

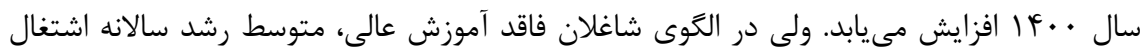

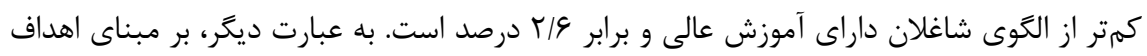

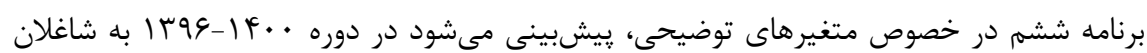

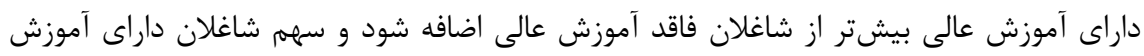

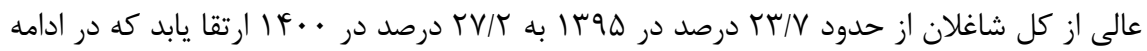
روند سال هاى كذشته است.

\section{بحث و نتيجه كيرى}

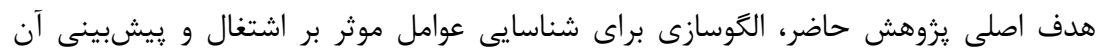

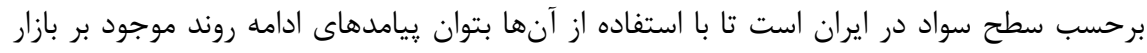

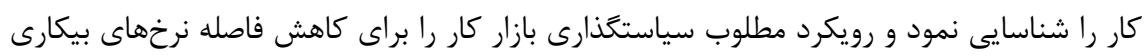

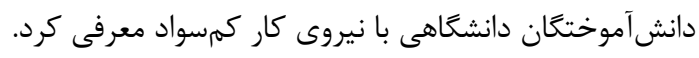

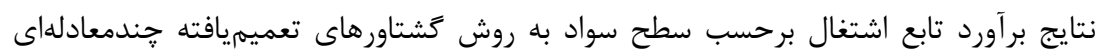




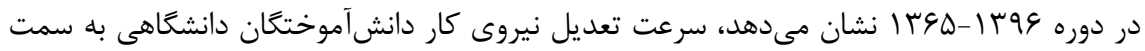
مقدار مطلوب آن در مقايسه با نيروى كار فاقد آموزش عالى بلهمراتب كندتر است كه اين مسئله به دو دليل است: ا. بخش عمده نيروى كار داراى آموزش عالى در بخش عمومى مشعى مشغول فعاليت است كه به دليل قوانين و مقررات استخدامى كشورى، كارفرماى دولتى قادر نيست نيروى كار مازاد خود را بهآسانى اخراج كند. از طرف ديكر، در مواردى كه نياز به نيروى كار وجود دارد، به دليل

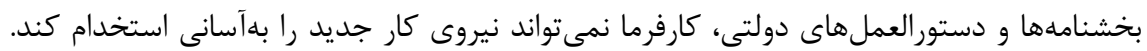

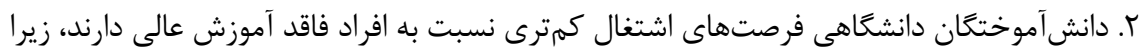

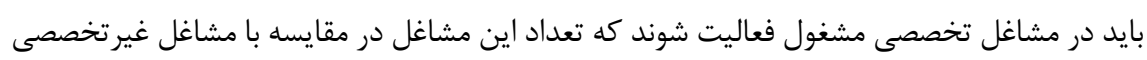

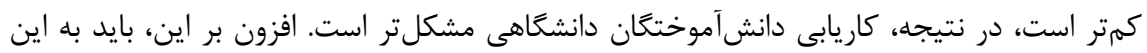

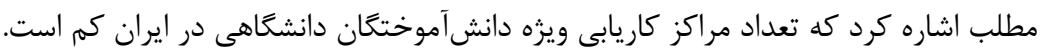

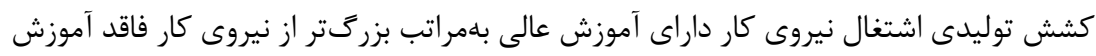

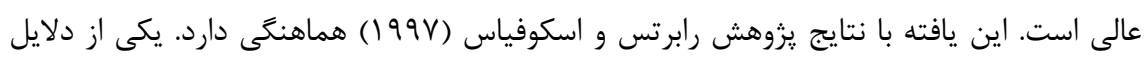

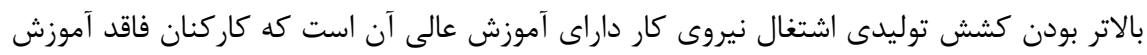

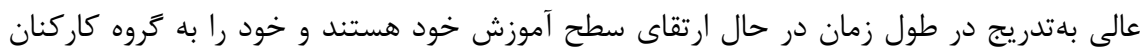
داراى آموزش عالى انتقال مىدهند. دليل ديكر مىتواند مربوط به حركت اقتصاد به سمت توست توسعه

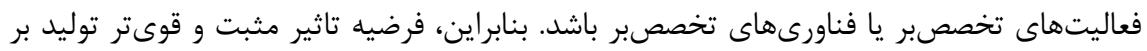

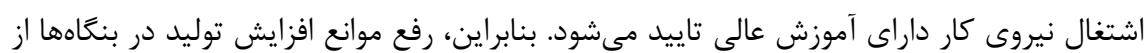

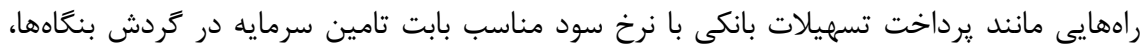

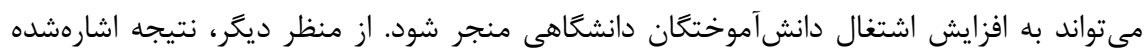

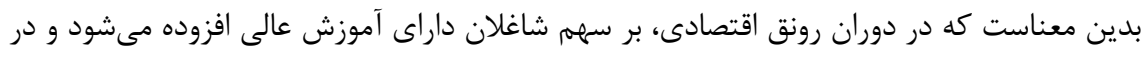
دوران ركود، برعكس. بر اساس اين، اجراى سياست يارانه دستمزد يا معافيت بيمه كارفرمايى براى

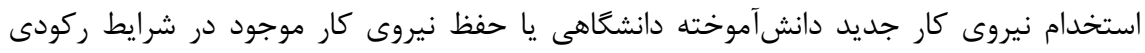

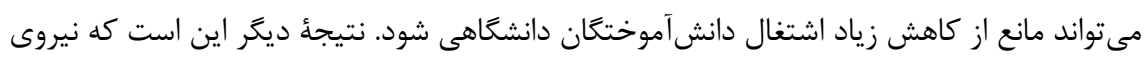

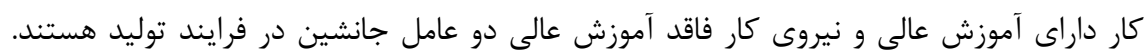

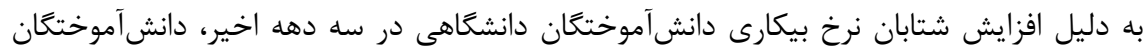

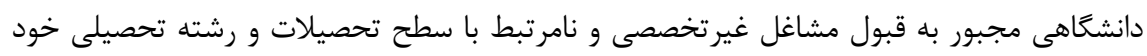

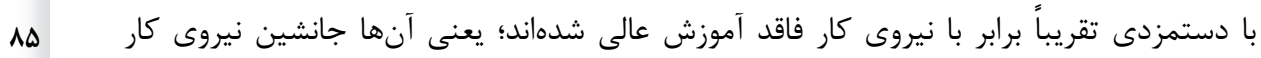


فاقد آموزش عالى شدهاند. براى مثال، بسيارى از افراد مشغول در باجههاى بانك داراى تحصيلات دانشگاهى هستند، در حالى كه اين سِمت در گذشته در اختيار افراد دييلمه بوده است يا برخى از

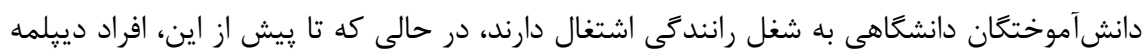

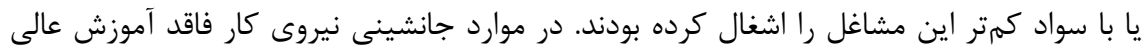

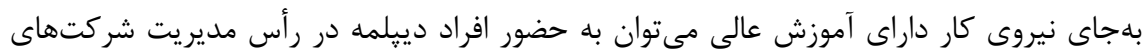
خصوصى و تعاونى اشاره كرد. در بخش خصوصى، به صرف اين كه فردى داراى سرمايه و تجربه كافى است، مىتواند در مشاغل مديريتى مشغول به كار شود. البته اين موضوع هم قابلقبول است كه كه

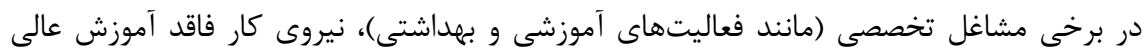

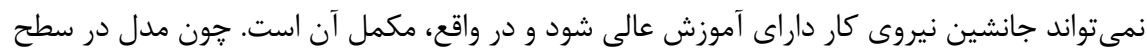

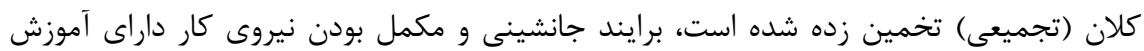

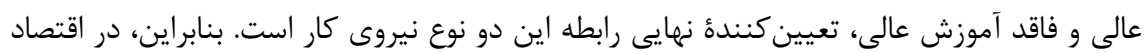

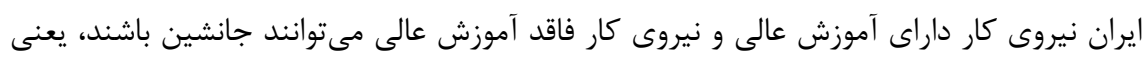

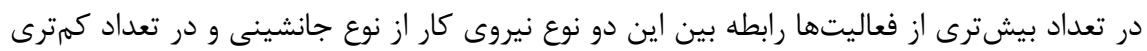

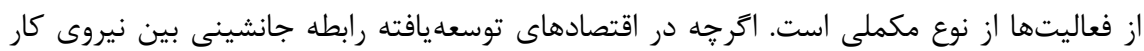

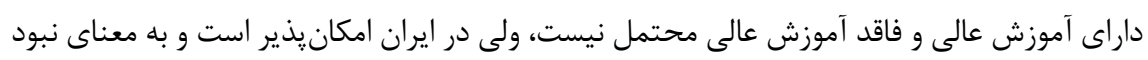

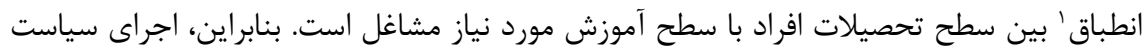

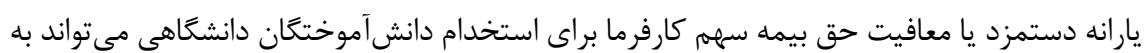
افزايش اشتغال نيروى كار داراى آموزش عالى منجر شود.

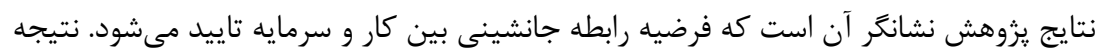
بهدستآمده حاكى از آن است كه يرداخت يارانه سود تسهيلات بانكى توسط دولت به سرمايهُ كذاران و كارفرمايان مىتواند به كاهش اشتغال منجر شود، مشروط بر اينكه اثر يادشده قوىتر از اثر يارانه سود تسهيلات بر سرمايهگذارى و توليد باشد. در نهايت، توسعه فناورى تاثير مثبت بر اشتغال

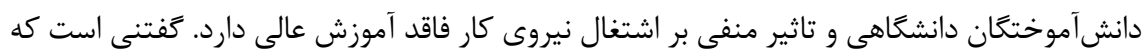

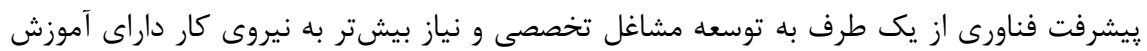
عالى منجر مىشود و از طرف ديكر، باعث مىشود تعدادى از مشاغل سنتى و ساده از بين بروند. ييشرفت فناورى از يك طرف به از بين رفتن مشاغل غيرتخصصى منجر مى شود و از طرف ديخر 
براى توليد هر واحد محصول به نيروى كار كمترى در خط توليد نياز است. كفتنى است كه بخش

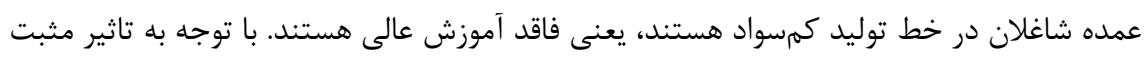

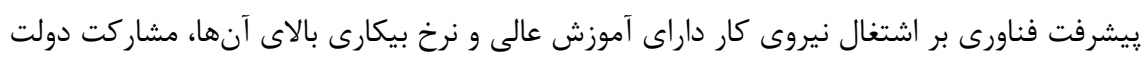

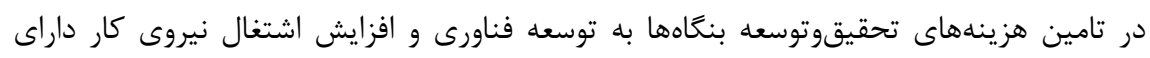

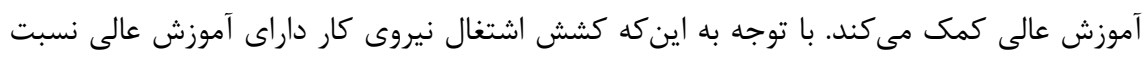

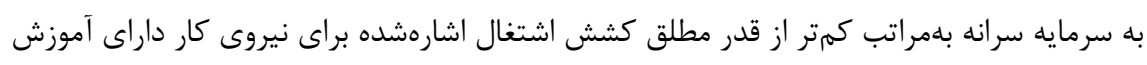

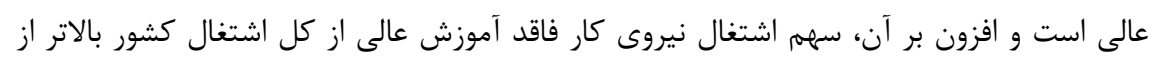

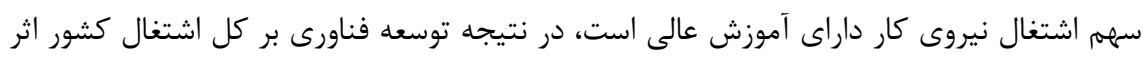
منفى دارد.

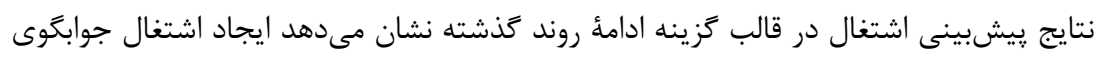

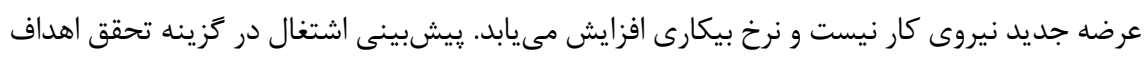

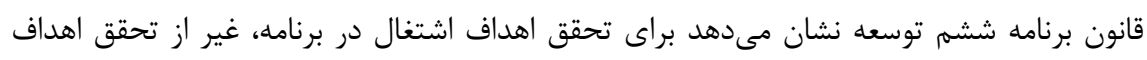

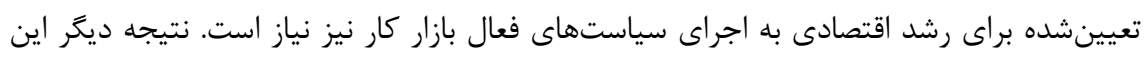

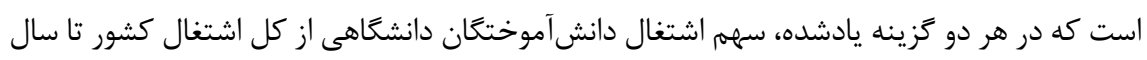

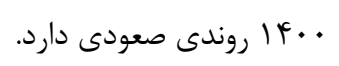

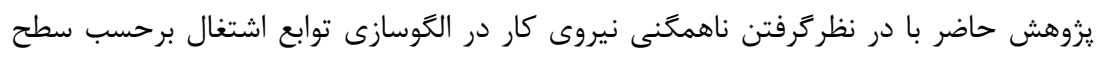

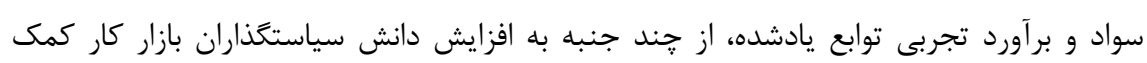

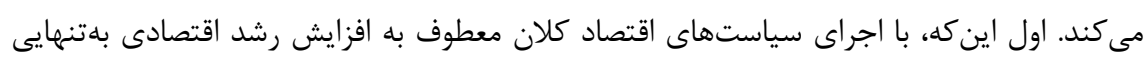

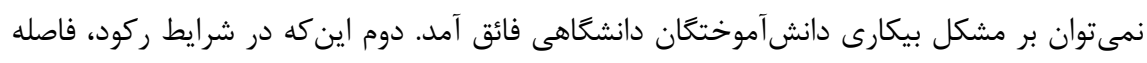

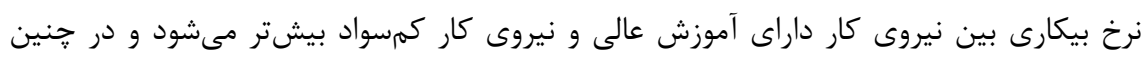

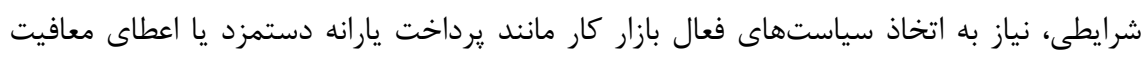

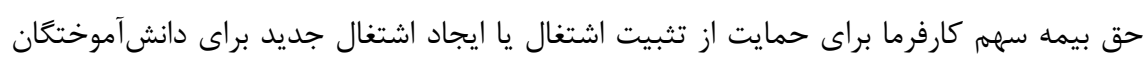

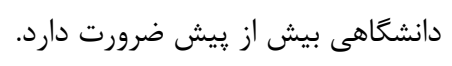

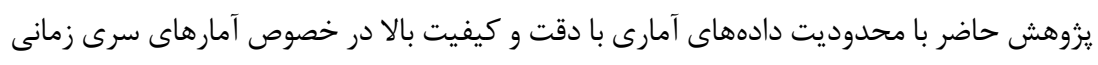

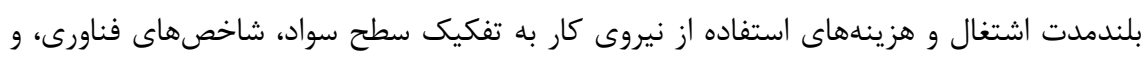

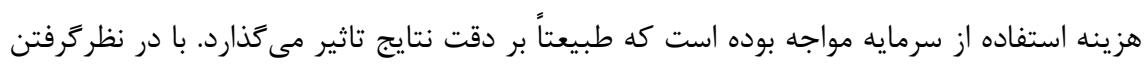

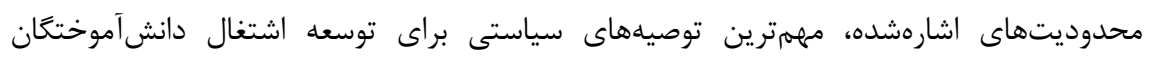


دانشگاهى عبارتاند از: ا. با توجه به رابطه جانشينى بين نيروى كار داراى آموزش عالى و نيروى

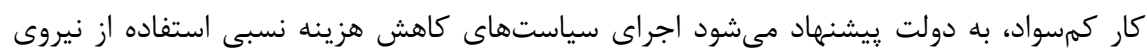
كار داراى آموزش عالى مانند اعطاى يارانه دستمزد، يرداخت حق به بيمه سهرم كارفرما توسط دولت،

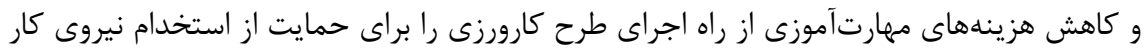
جديد دانشآموخته دانشگاهى در دوران رونق و ركود در دستور كار قرار دهد. r. با توجه به اينكه

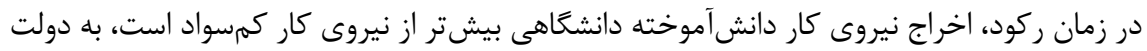

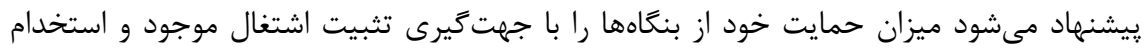

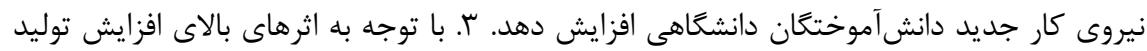

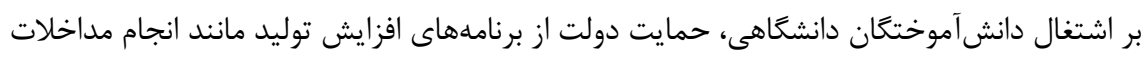
توسعهاى به منظور تكميل زنجيره ارزش رسته فعاليتهاى اقتصادى يراشتغال و داراى ظرفيت

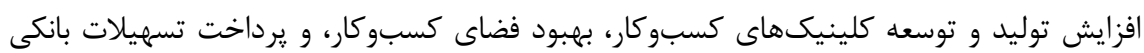

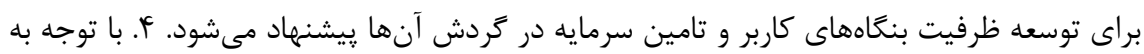

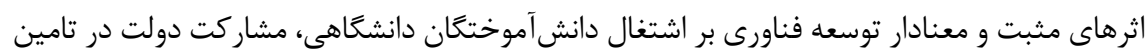
هزينههاى تحقيقوتوسعه بنَاهها به منظور توسعه فناورى توصيه مى گردد.

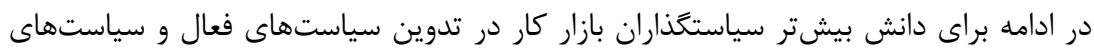

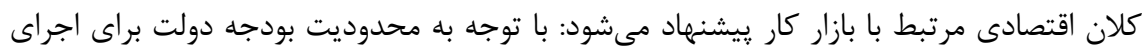

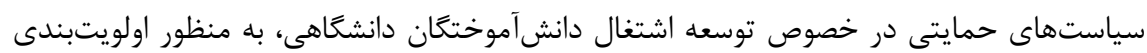
فعاليتهاى اقتصادى، توابع اشتغال برحسب سطح سواد به تفكيك فعاليتهاى اقتصادى برآورد

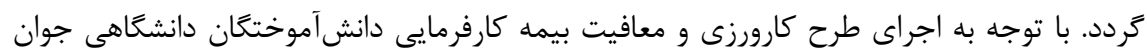

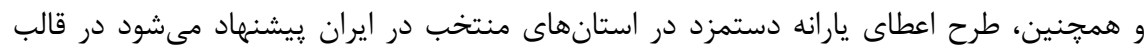
يزوهش ميدانى، اثربخشى طرحهاى يادشده ارزيابى گردد. همجنين، با توجه به اثرهاى مثبت و منفى لئى يرداخت يارانه سود تسهيلات بانكى بر اشتغال، يِيشنهاد مىشود اثرهاى يرداخت يارانه سود تسهيلات بانكى بر اشتغال از كانالهاى مختلف ارزيابى كردد.

\section{اظهاريه}

اين يزوهش بركرفته از طرح مطالعاتى برآورد توابع اشتغال برحسب فعاليتهاى اصلى اقتصادى،

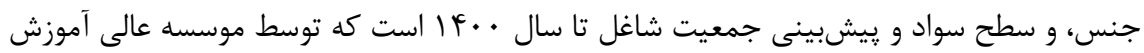




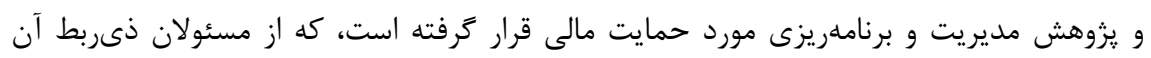

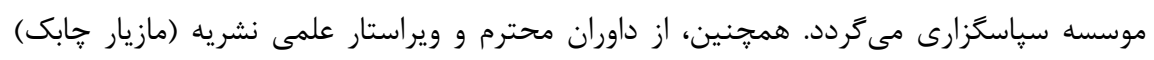

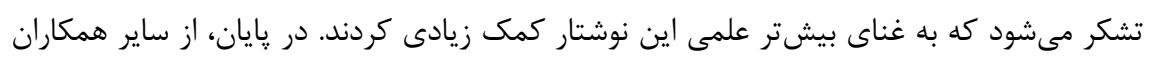

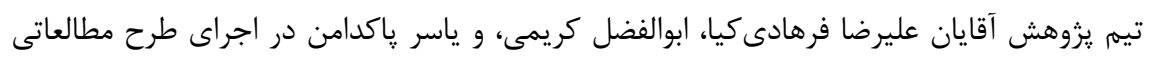

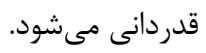

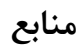

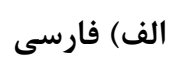

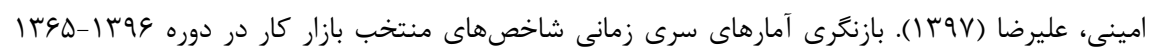

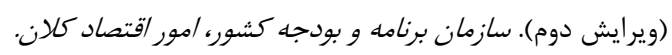

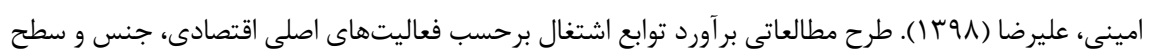

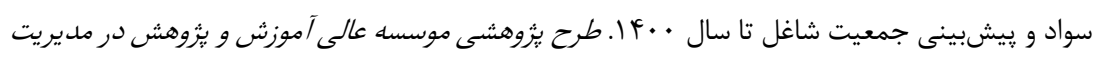

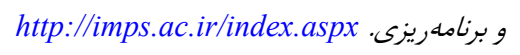

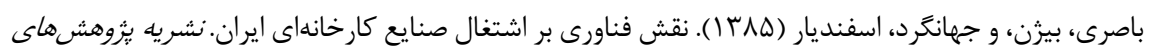

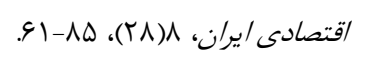

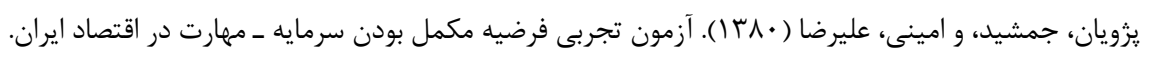

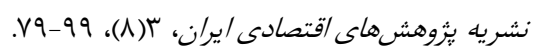

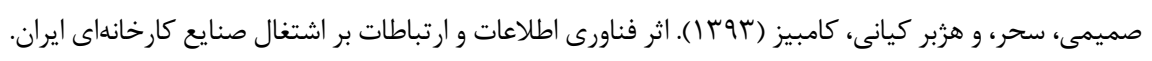

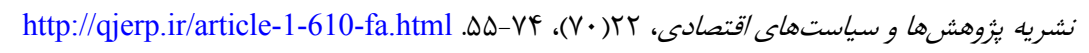

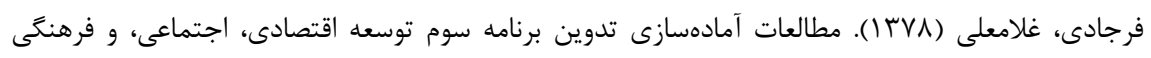

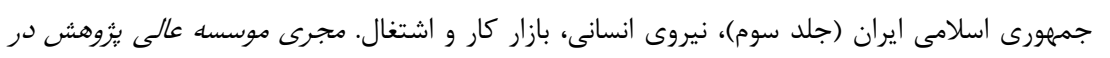

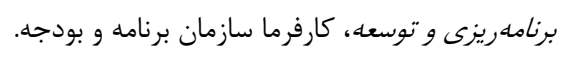

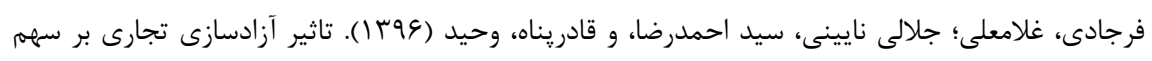

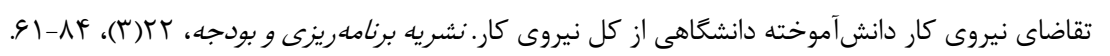
http://jpbud.ir/article-1-1487-fa.html

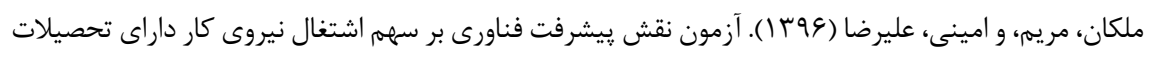

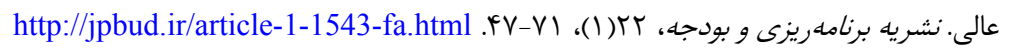


منظور، داود، و بهاءلو هوره، مرضيه (4 (1) ). تحليل اثرات افزايش حداقل دستمزد بر اشتغال نيروى كار ساده و ماهر در

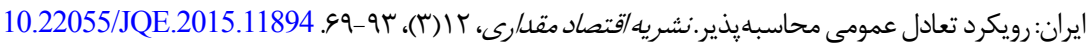

Borjas, G. (2005). Labor Economics: Mcgraw. Nill.

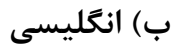

Bresson, G., Kramarz, F., \& Sevestre, P. (1992). Heterogeneous Labor and the Dynamics of Aggregate Labor Demand: Some Estimations Using Panel Data. Empirical Economics, 17(1), 153-167. https://doi.org/10.1007/BF01192481

Cahuc, P., \& Zylberberg, A. (2004). Labor Economics: Cambridge, MA: MIT Press.

Chennells, L., \& Reenen, J. V. (1999). Has Technology Hurt Less Skilled Workers? An Econometric Survey of the Effects of Technical Change on the Structure of Pay and Jobs. IFS Working Papers, No. W99/27. doi:10.1920/wp.ifs.1999.9927

Hayashi, F. (2000). Econometrics: Princeton University Press.

O'Mahony, M., Robinson, C., \& Vecchi, M. (2008). The Impact of ICT on the Demand for Skilled Labour: A Cross-Country Comparison. Labour Economics, 15(6), 1435-1450. https://doi.org/10.1016/j.labeco.2008.02.001

Roberts, M. J., \& Skoufias, E. (1997). The Long-Run Demand for Skilled and Unskilled Labor in Colombian Manufacturing Plants. Review of Economics and Statistics, 79(2), 330-334.

Sabia, J. J., Burkhauser, R. V., \& Hansen, B. (2012). Are the Effects of Minimum Wage Increases Always Small? New Evidence from a Case Study of New York State. Ilr Review, 65(2), 350-376. https://doi.org/10.1177/001979391206500207

Salvatore, D. (1987). Theory and Problems of International Economics: McGraw Hill Book Company. 